\title{
Bioengineering cobalt chromium cardiovascular stent biomaterial for biofunctionalization
}

\author{
Thamarasee M. Jeewandara ${ }^{1}$ \\ ${ }^{1}$ Sydney Medical School, University of Sydney, Sydney, NSW, Australia
}

\begin{abstract}
Suboptimal biocompatibility of cardiovascular stents manifest as non-compliance at stent-artery interface in vivo. We optimized a plasma-activated coating (PAC) technology to modify cobalt chromium alloy L605 (PAC-L605) surface of an implantable coronary stent material, for improved biofunctionalization. The PAC-L605 surfaces displayed covalent binding capacity of a protein candidate tropoelastin (TE) by retaining $70.3 \%$ of TE after SDS detergent washing. Human coronary artery endothelial cell (HCAEC) proliferation visualized with crystal violet staining, did not vary significantly among the biomaterials at 3 or 5 days. Anchorage of cell cytoskeleton visualized with immunofluorescence and scanning electron microscopy (SEM), showed homogenous cell morphology on PAC/TE (with TE) surfaces. Surface hemocompatibility was assessed with static and flow blood assays, the hydrophilic PAC-L605 displayed lower clot formation compared to L605. Area of surface fibrinogen deposited was significantly lower on PAC-L605 vs. L605. Selected ISO 10993-4 tests for biological evaluation of medical devices in contact with blood indicated significantly lowered plasma markers of thrombin-antithrombin complex (TAT), beta-thromboglobulin ( $\beta$-TG), soluble P-selectin and soluble terminal complement complex (SC5b-9) on PAC-L605 vs. L605. There was no significant difference for plasma biomarkers of polymorphonuclear elastase (PMN elastase) on PAC-L605 vs. L605. Improved surface biofunctionalization of implantable cardiovascular materials could be achieved by plasma-activated coating (PAC).
\end{abstract}

\section{Introduction}

Evaluating biological design from an engineering perspective, aid researchers develop medical device surfaces with improved biocompatibility for clinical applications. Micro/nanostructured surfaces are developed to improve biomimicry during interaction with micro/nanoscale living tissue (Coutinho et al. 2011). In bioengineering, 'biofunctionalization' is the modification of a material to have biological function (Nyanhongo, Steiner, and Gübitz 2011), and elicit appropriate responses during its applications simulated in vitro and translated in vivo. Key limitations post stent implantation include thrombosis, neointimal hyperplasia (NIH), restenosis and late stent thrombosis (LST) (Cutlip et al. 2007). Cardiovascular stent surface modifications aim to overcome these limitations via optimized interactions with cells, protein and blood at the artery-material interface, reviewed elsewhere (Jeewandara, Wise, and Ng 2014).

The advent of second generation drug-eluting stents (DES), caused significant reduction to the incidence of restenosis and late myocardial infarction (MI) (Alhejily and Ohman 
bioRxiv preprint doi: https://doi.org/10.1101/042770; this version posted March 9,2016 . The copyright holder for this preprint (which was not certified by peer review) is the author/funder, who has granted bioRxiv a license to display the preprint in perpetuity. It is made available under aCC-BY-NC-ND 4.0 International license.

2012). However, among patients with clinical complications, risk of restenosis, stent thrombosis and possible MI still exists (Alhejily and Ohman 2012). Tissue engineering hydrophilic surfaces for research applications aim to; prevent surface aggregation of proteins whilst facilitating controlled protein attachment (Malmsten 1998, Waterhouse et al. 2011, Yin et al. 2009), assist anchorage of healthy cell cytoskeleton on materials for endothelialization (Wozniak et al. 2004), promote surface hemocompatibility (Prentner et al. 2010) and promote biofunctionalization of medical devices in contact with blood in accordance to ISO 10993-4 tests (Seyfert, Biehl, and Schenk 2002).

The present study utilized a proprietary applied plasma physics technique (Bilek et al. 2011) to modify the surface of cardiovascular stent material alloy L605. The plasmaactivated coating (PAC) constructs a buffer layer at the interface of organic and inorganic materials forming a robust surface; characterized previously on PAC-L605 (Jeewandara 2016). The surface modification is unique, non-delaminating and able to covalently bind tropoelastin (TE), a bioactive protein candidate of interest (Waterhouse et al. 2011). In the present study, we investigated biofunctionalization of PAC-L605 vs. L605 via 4 aims:

1. Comparative covalent binding capacity of tropoelastin (TE) to surfaces.

2. Human coronary artery endothelial cell (HCAEC) proliferation to determine endothelialization on PAC-L605 vs. PAC-L605/TE (with tropoelastin) vs. L605.

3. Hemocompatibility assays to determine thrombogenicity of PAC-L605 vs. PACL605/TE vs. L605.

4. Enzyme linked immunoabsorbent assays (ELISA) to determine concentration of biochemical markers of thrombosis, platelet, complement and leukocyte activation, after blood-material contact (table 1).

Table 1: ISO 10993-4 selected tests for biological evaluation of medical device material interaction with blood.

\begin{tabular}{|l|l|}
\hline \multicolumn{1}{|c|}{ ELISA test } & \multicolumn{1}{|c|}{$\begin{array}{c}\text { Molecular marker/cascade } \\
\text { investigated }\end{array}$} \\
\hline Thrombin-Antithrombin complex (TAT) & Thrombosis/Coagulation \\
\hline Beta-Thromboglobulin $(\beta-T G)$ & Platelet activation \\
\hline Soluble P-selectin (sP-selectin) & Platelet activation \\
\hline Soluble terminal complex C5b-9 (SC5b-9/TCC) & Complement activation (immunology) \\
\hline $\begin{array}{l}\text { Polymorphonuclear neutrophil elastase (PMN } \\
\text { elastase) }\end{array}$ & Leukocyte activation (hematology) \\
\hline
\end{tabular}

\section{Materials and Methods}

\section{Preparation of cobalt chromium alloy L605 for surface modification}

Samples of alloy L605 (10 cm x $8 \mathrm{~cm} \times 0.025 \mathrm{~cm})$ were prepared as before (Jeewandara 2016). All experiments were carried out with freshly made PAC, used within 2 weeks, unless stated otherwise. 
bioRxiv preprint doi: https://doi.org/10.1101/042770; this version posted March 9, 2016. The copyright holder for this preprint (which was not certified by peer review) is the author/funder, who has granted bioRxiv a license to display the preprint in perpetuity. It is made available under aCC-BY-NC-ND 4.0 International license.

\section{Synthesis of plasma-activated coating}

The cleaned substrates were mounted onto a stainless steel cylindrical ccrf reactor. Base pressure of the system was pumped down to $10^{-6}-10^{-5}$ Torr. A reactive mixture of argon, nitrogen and acetylene plasma was introduced in the upper part of the reactor. The flow, $Q$, of each gas for alloy L605 surface; $Q_{\text {Argon }}=3 \mathrm{sccm}, Q_{\text {Acetylene }}=1 \mathrm{sccm}$, and $Q_{\text {Nitrogen }}=10$ $\operatorname{sccm}(500 \mathrm{~V}, \mathrm{t}=20 \mathrm{~min})$, was controlled individually, using mass flow controllers and maintained constant, during coating deposition (PAC1 recipe). On another alloy L605 sample of similar dimensions, we trialed a second recipe $Q_{\text {Argon }}=3 \mathrm{sccm}, Q_{\text {Acetylene }}=2 \mathrm{sccm}$ and $Q_{\text {Nitrogen }}=10 \mathrm{sccm}(1000 \mathrm{~V}, \mathrm{t}=10 \mathrm{mins})$ (PAC2 recipe). Plasma was sustained at a total pressure of 80 mTorr, rf power $50 \mathrm{~W}$, and deposition time of 10-20 mins. Unless specified, two recipes of PAC (PAC1/PAC2) were investigated simultaneously.

\section{Tropoelastin (TE) coating and SDS-ELISA detection}

Recombinant human tropoelastin (TE) used in previous studies (Waterhouse et al. 2010) was similarly expressed and purified from E.coli expression system (Martin, Vrhovski, and Weiss 1995). The PAC-L605 and alloy L605 samples $(0.8 \mathrm{~cm} \times 0.8 \mathrm{~cm})$ were incubated with $250 \mu \mathrm{l}$ of $50 \mu \mathrm{g} / \mathrm{ml}$ tropoelastin in phosphate buffered saline (PBS), at $4^{\circ} \mathrm{C}$ overnight. SDS detergent treatment and ELISA for characterization of bound TE was carried out as previously described (Yin et al. 2009).

\section{Cell culture and proliferation}

Cell assays were performed in triplicate in tissue culture plastic (TCP) 24-well plates containing samples of L605, PAC-L605 and PAC-L605/TE $(0.6 \mathrm{~cm} \times 0.6 \mathrm{~cm})$. HCAECs were seeded and left to proliferate for 3 or 5 days. Cell proliferation was quantified by crystal violet staining and measurements of absorbance at $570 \mathrm{~nm}$.

\section{Immunofluroscent detection of cell cytoskeleton}

Metallic samples with or without tropoelastin $(50 \mu \mathrm{g} / \mathrm{ml})$ were seeded with HCAECs. Five biomaterial surfaces were investigated: 1. PAC-L6051 recipe, 2. PAC-L6052 recipe, 3. PAC 1 recipe with tropoelastin (TE), 4. PAC 2 recipe with TE, 5 . Cobalt chromium bare metal alloy L605. After day 5 cell culture, samples were incubated with $0.2 \mathrm{M}$ glycine for $20 \mathrm{~min}$ and fixed in triton X-100 (0.2\% v/v in PBS) for 10 min. Cells were blocked in $5 \%(\mathrm{w} / \mathrm{v})$ BSA in PBS for 1 hour. Samples were stained with human anti-vWF antibody (Dako, 1:400 in PBS) for $30 \mathrm{~min}$, washed thrice in PBS and incubated with goat anti-rabbit IgG Alexa Fluor ${ }^{\circledR} 488$ (Abcam, 1:90 in PBS) for 1 hour. Samples were stained with phalloidin-TRITC (Sigma, $0.1 \mu \mathrm{g} / \mathrm{ml}$ in 3\% BSA) for $45 \mathrm{~min}$ washed thrice with PBS and stained with DAPI (Sigma, $0.15 \mu \mathrm{g} / \mathrm{ml}$ in PBS) for $15 \mathrm{~min}$. Samples were imaged with an Olympus IX70 inverted microscope using a 40x objective.

\section{Scanning Electron Microscopy (SEM) detection of cell cytoskeleton}

HCAECs were cultured for 2 days on three sample surfaces: L605, PAC-L605 and PACL605/TE. Samples were washed in PBS, fixed in 4\% formaldehyde for $30 \mathrm{~min}$ at room temperature (RT), dehydrated in ascending grades of ethanol $(30 \% \mathrm{v} / \mathrm{v}$ to $100 \% \mathrm{v} / \mathrm{v}, 5$ min each) before chemical drying with hexamethyldisilazine (HMDS). The samples were mounted to stubs using carbon tape, sputter coated with $20 \mathrm{~nm}$ gold and imaged with Zeiss Ultra field emission scanning electron microscope (FESEM). 
bioRxiv preprint doi: https://doi.org/10.1101/042770; this version posted March 9, 2016. The copyright holder for this preprint (which was not certified by peer review) is the author/funder, who has granted bioRxiv a license to display the preprint in perpetuity. It is made available under aCC-BY-NC-ND 4.0 International license.

\section{Hemocompatibility assays}

\section{Blood sampling and platelet rich plasma (PRP) isolation for static assay}

Whole blood was obtained as previously described (Waterhouse et al. 2010). All experiments were conducted in triplicate samples at least thrice with different donor's blood. Samples of L605, PAC-L605 and PAC-L605/TE $(0.8 \mathrm{~cm} \times 0.8 \mathrm{~cm})$ were placed in a 24 well plate blocked with 3\% BSA in PBS for 1 hour at RT and washed thrice with PBS. Blood was anti-coagulated with $0.5 \mathrm{U} / \mathrm{ml}$ heparin and centrifuged for $15 \mathrm{~min}$ at $1000 \mathrm{rpm}$. The supernatant was removed and samples incubated with 250-500 $\mu$ of PRP for $60 \mathrm{~min}$ at $37^{\circ} \mathrm{C}$ while rocking. Samples processed for SEM as above were additionally post-fixed with $\mathrm{OsO}_{4}$ (ProSciTech, $0.1 \%$ in $0.1 \mathrm{M} \mathrm{PB}$ ) for 1 hour, prior to dehydration process.

\section{Ageing study on thrombogenicity}

An ageing study was conducted with PRP to analyze surface thrombogenicity over time. The samples were 1) 1-month old PAC-L605, 2) 1 month old PAC-L605 with TE stored for 2 weeks at $\left.-20^{\circ} \mathrm{C}, 3\right) 1$ month old PAC-L605 incubated with TE stored overnight at $4^{\circ} \mathrm{C}$ and 4) bare alloy L605 (control). Samples were placed in a 24 well plate and incubated with PRP at $37^{\circ} \mathrm{C}$ for $60 \mathrm{~min}$, and processed for SEM imaging.

\section{Whole blood adhesion assays}

Samples PAC-L605 and L605 $(0.8 \mathrm{~cm} \times 0.8 \mathrm{~cm})$ were incubated with $500 \mu \mathrm{l}$ of heparinized whole blood $(0.5 \mathrm{U} / \mathrm{ml})$ for a period of 30,60 , and $90 \mathrm{~min}$ at $37^{\circ} \mathrm{C}$ while rocking, to assess variation of surface hemocompatibility with time of flow. Samples were processed for SEM imaging.

\section{Whole blood flow assays - Modified chandler loop system}

Coagulation under flow was investigated with a modified chandler loop system at physiological conditions in vitro as previously described (Gaamangwe 2014, Waterhouse et al. 2010). The blood sample volume and dimensions of all material samples met ISO 10993-12 regulations (Gaamangwe 2014). Clot formation was quantified for sample surfaces of; 1 -week old PAC recipe 1 vs. PAC recipe 2 vs. L605, followed by PAC-L605 vs. PAC/TE vs. L605, and 5-month old PAC-L605 vs. L605. Plasma from whole blood was separately isolated for surface fibrinogen detection and ISO-10993-4 selected ELISA tests.

\section{Surface Fibrinogen detection}

Fibrinogen staining helped visualize surface fibrin deposited on biomaterials after blood flow assay. A stock solution of fibrinogen Alexa Fluor ${ }^{\circledR} 488$ was prepared (Life Technologies, $5 \mathrm{mg}$ fibrinogen in $3.3 \mathrm{ml}$ of $0.1 \mathrm{M} \mathrm{NaHCO}_{3}, \mathrm{pH} 8.3$, at RT) and gently agitated for 1 hour. Samples (PAC-L605 and L605) were removed from chandler loop and incubated in a 24-well plate with a volume of $250 \mu$ l fibrinogen-Alexa Fluor ${ }^{\circledR} 488$ (1:60 dilution in distilled water) for $15 \mathrm{~min}$. The samples were washed with PBS and incubated with DAPI (Sigma, $0.15 \mu \mathrm{g} / \mathrm{ml}$ in PBS) for $15 \mathrm{~min}$. Samples were imaged with an Olympus IX70 inverted microscope using a 10x objective. Surface fibrinogen on 5 areas per sample image, were quantified and averaged with 'smart segmentation' tool, Image Pro Premier software (Media Cybernetics, USA). 


\section{ELISA for biomarkers of coagulation, inflammation and complement activation}

Whole blood samples from chandler loop assay were centrifuged at following conditions to isolate plasma prior to ELISA tests (table 2).

Table 2: Centrifuge conditions of plasma isolation for individual ELISAs.

\begin{tabular}{|l|l|l|l|}
\hline & \multicolumn{3}{|c|}{ Plasma Isolation Conditions } \\
\hline ELISA test for biomarker & $\begin{array}{l}\text { Centrifugation Speed } \\
(\mathrm{x} \mathrm{g})\end{array}$ & $\begin{array}{l}\text { Time } \\
(\mathrm{min})\end{array}$ & Anticoagulant \\
\hline $\begin{array}{l}\text { Thrombin Antithrombin } \\
(\mathrm{TAT})\end{array}$ & 3000 & 10 & $10 \%$ citrate \\
\hline $\begin{array}{l}\text { Beta thromboglobulin }(\beta- \\
\text { TG) }\end{array}$ & 1000 & 20 & $10 \%$ citrate \\
\hline Soluble P-selectin & 1000 & 15 & $10 \%$ citrate \\
\hline SC5b-9 complex & 10,000 & 5 & $10 \% \mathrm{~K}_{2}$ EDTA \\
\hline PMN elastase & 1500 & 10 & $10 \% \mathrm{~K}_{2}$ EDTA \\
\hline
\end{tabular}

The concentrations of TAT complex (abcam, Cambridge, MA, USA), $\beta$-TG (MyBioSource, San Diego, CA, USA), sP-selectin (LifeTechnologies, Vic, Aus), SC5b-9 terminal complement complex (MicroVue, Quidel, San Diego, CA, USA) and PMN elastase (abcam, Cambridge, MA, USA) were quantified according to manufacturer's protocol. Plasma biomarkers of sP-selectin, SC5b-9 and PMN elastase were respectively diluted by factors of 1:30, 1:10 and 1:100 in specimen diluent. Manufacturer-provided high and low controls for SC5b-9 and PMN elastase, were used in ELISA tests in similar dilution to the samples. Concentration readings to identify presence of biomarkers - TAT was performed at $450 \mathrm{~nm}$ with a $570 \mathrm{~nm}$ wavelength correction, $\beta$-TG at $450 \mathrm{~nm}$, sP-selectin at $450 \mathrm{~nm}$ with a $620 \mathrm{~nm}$ wavelength correction, TCC/SC5b-9 complex at $450 \mathrm{~nm}$ and finally PMN elastase at $450 \mathrm{~nm}$ with a $620 \mathrm{~nm}$ wavelength correction. All experiments were conducted in triplicate samples.

\section{Statistics}

Data are expressed as mean \pm standard deviation. Data were analyzed by paired t-test and ordinary one-way ANOVA with multiple comparisons for $>2$ variables. For ELISA test results, the unknown concentrations were calculated with nonlinear regression (curve fit). Standard curves to interpolate hyperbola (X is concentration) were selected with fitting method (least squares ordinary fit) to interpolate unknowns, using GraphPad Prism version 6.00 (Graphpad software, San Diego, CA, USA) for MAC OS X. 


\section{Results}

Covalent protein binding capacity of PAC surfaces were determined using an elastinspecific ELISA. In the absence of tropoelastin (TE), background levels of absorbance were $0.012 \pm 0.009$ on PAC-L605 and $0.010 \pm 0.014$ on alloy L605 respectively (Figure 1). Absorbance readings without SDS washing for PAC-L605 vs. L605 was $0.202 \pm 0.01$ and $0.138 \pm 0.005$ respectively. SDS washing was used to remove non-covalently bound protein, after which readings decreased to $0.142 \pm 0.011$ for PAC-L605 (29.70\% reduction) and $0.041 \pm 0.009$ for L605 (70.28\% reduction). The modified PAC-L605 displayed covalent binding capacity by retaining $70.3 \%$ of bound TE after SDS wash.

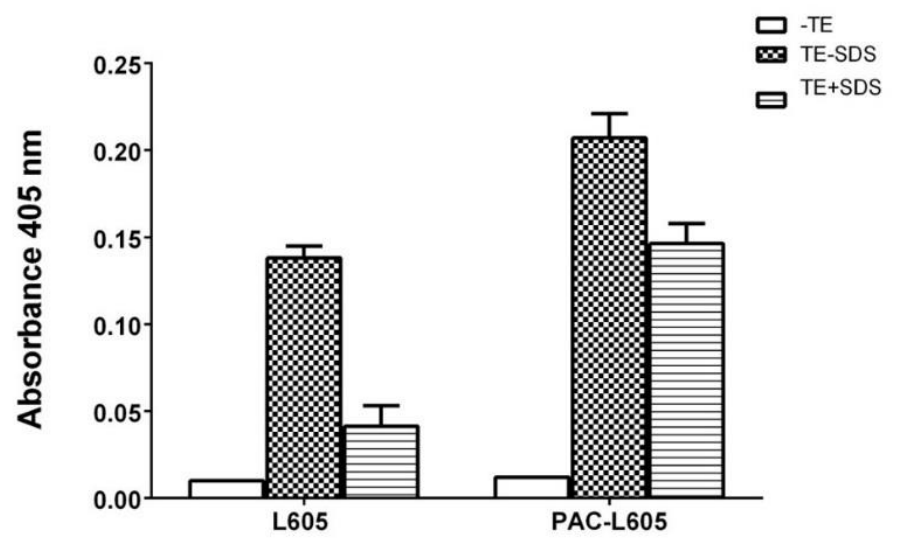

Figure 1: ELISA with anti-elastin antibody to detect covalent binding capacity of TE to plasma-modified PAC-L605 surfaces, compared to bare metal alloy L605. The TE-SDS samples (checked) were not washed with SDS detergent, the TE+SDS samples (stripes) were washed with SDS detergent. The blanks are negative controls.

\section{Proliferation and anchorage of HCAECs: cell-material interactions}

HCAEC proliferation at day 3 and day 5 were quantified on biomaterials L605, PAC-L605 and PAC-L605/TE (with TE). Tissue culture plastic (TCP) was the positive control. At day 3 , absorbance readings at $570 \mathrm{~nm}$ for TCP vs. L605 vs. PAC-L605 vs. PAC-L605/TE were $0.272 \pm 0.034,0.126 \pm 0.012,0.135 \pm 0.013$ and $0.119 \pm 0.009$ respectively. At day 5, absorbance for material surfaces in the same order were $0.535 \pm 0.017,0.194 \pm 0.014$, $0.271 \pm 0.016$ and $0.304 \pm 0.048$ respectively. Cell proliferation was significantly higher for TCP (positive control, not shown), although not significantly different among biomaterials of interest at day 3 or 5 cell culture (Figure 2). 

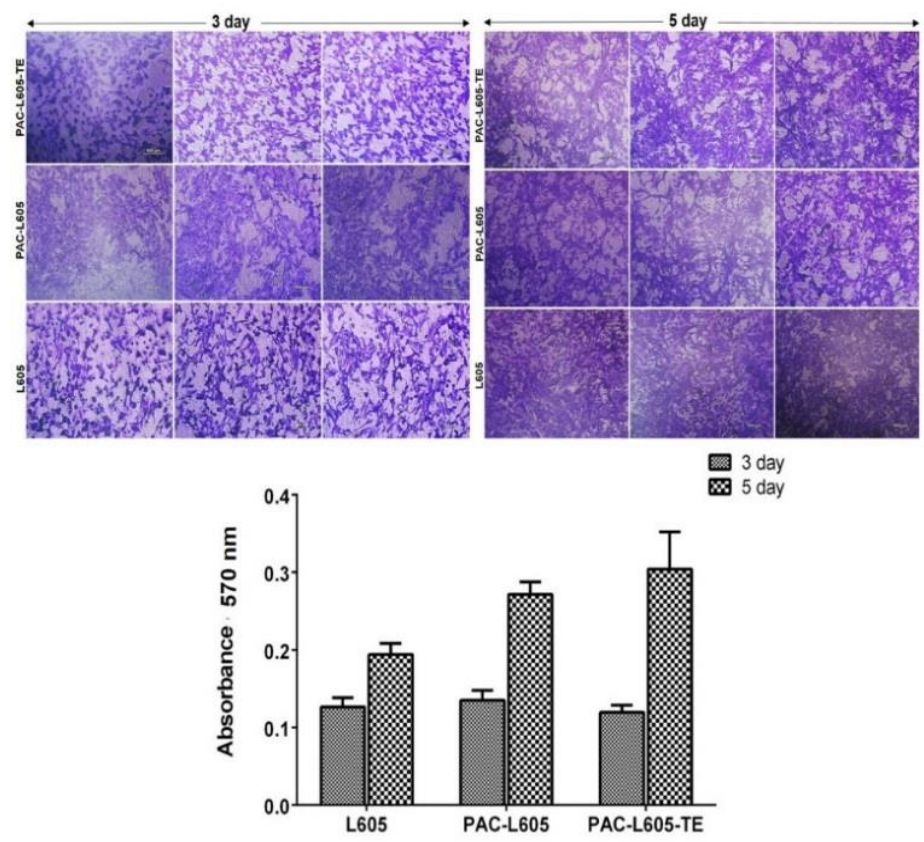

Figure 2: Figure panels on top indicate crystal violet stained HCAEC proliferation on PAC-L605/TE, PAC-L605 and alloy L605, at day 3 and day 5 respectively $(10 x$ magnification, scale bar 200 $\mathrm{mm}$ ). The graphed absorbance of surface cell density increased progressively from day 3 to day 5, although results were not significantly different among the biomaterials at either time point of study.

Filamentous actin (F-actin) anchorage of HCAECs to biomaterials were visualized with inverted fluorescence microscopy on 5 different biomaterial surfaces at day 5 proliferation (40 x magnification). Homogenous distribution of F-actin was observed on PAC2-L605 surfaces compared to PAC1-L605. Similar trends were also observed with PAC2-L605 with TE (Figure 3). The PAC2 recipe was chosen for further cell experiments hitherto referred as PAC-L605.

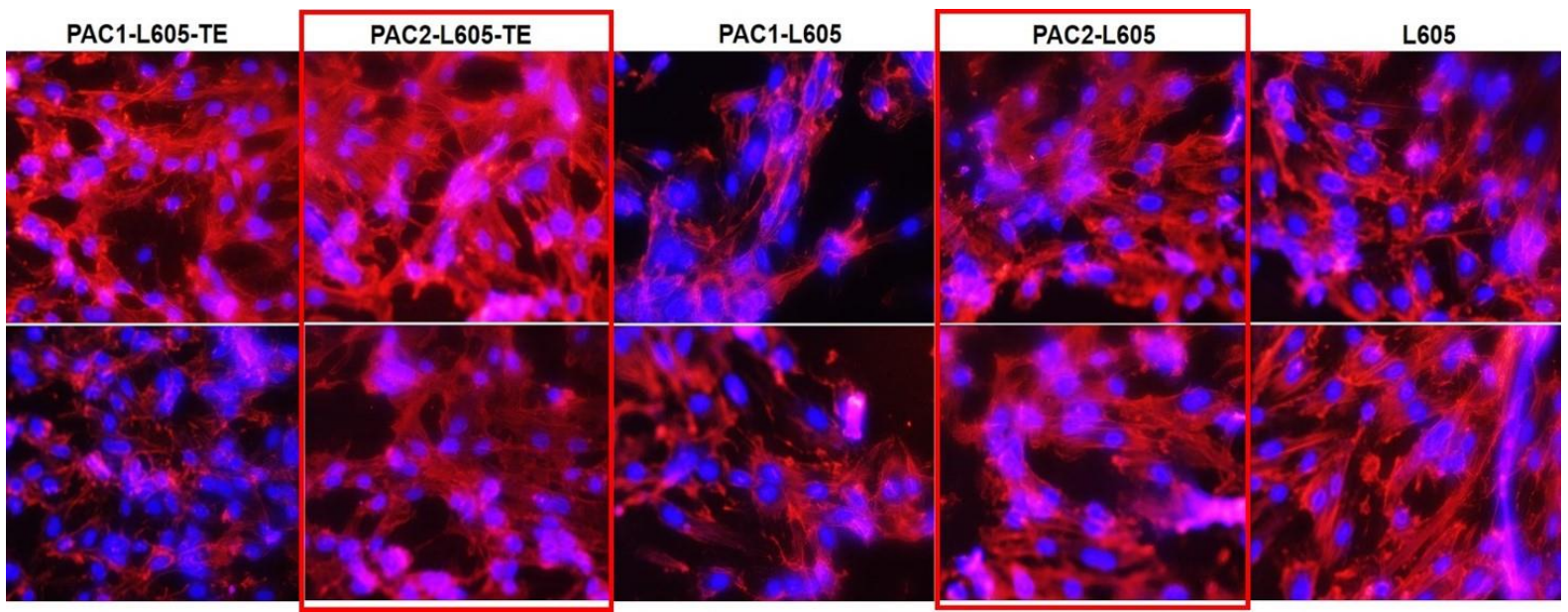

Figure 3: The F-actin anchorage on biomaterials were visualized with phalloidin-TRITC staining at $40 \times$ magnification (fluorescent channel, inverted Olympus microscope). The cytoskeleton spread homogenously (F-actin) on PAC2 surfaces, with or without tropoelastin (TE), recipe chosen for further experiments in cell culture. 
bioRxiv preprint doi: https//doi org/10.1101/042770; this version posted March 9 2016. The copyright holder for this preprint (which was not certified by peer review) is the author/funder, who has granted bioRxiv a license to display the preprint in perpetuity. It is made available under aCC-BY-NC-ND 4.0 International license.

Distribution of F-actin, vWF and cell nuclei (triple stain) were visualized for HCAECs on PAC-L605 vs. L605 (40 x magnification). Endothelial cells on PAC-L605 appeared more confluent and homogenous in distribution compared to HCAECs on L605.

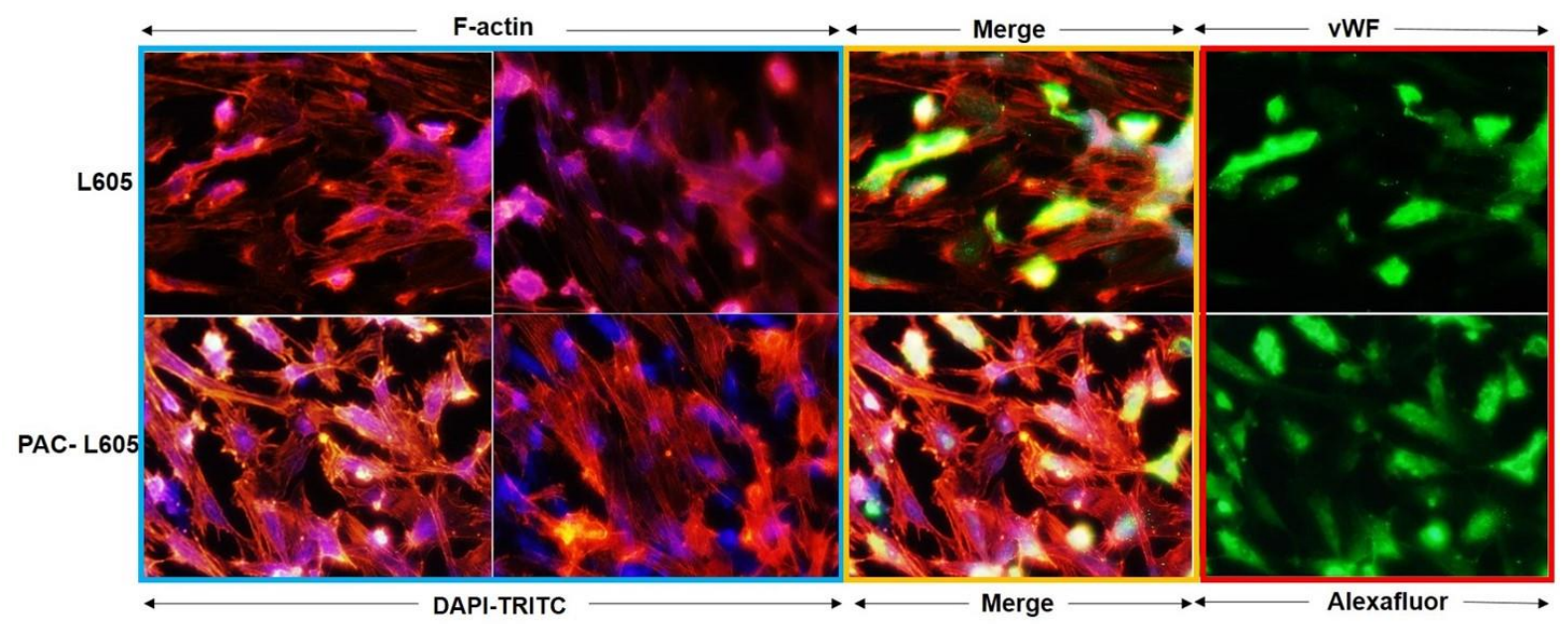

Figure 4: Filamentous actin visualized on PAC-L605 and L605 surfaces at 40x magnification with phalloidin-TRITC and DAPI after day 5 proliferation. Image shows well defined cytoskeleton on PAC-L605 compared to L605 (blue box). Merged triple stain (yellow) and endothelial specific vWF staining uptake (red box).

The HCAEC morphology on L605, PAC-L605 and PAC-L605/TE material surfaces were visualized after day 2 proliferation with scanning electron microscopy (Figure 5). The PAC-L605/TE (with tropoelastin) showed least spindle projections, homogenous cell cytoskeleton distribution and support for HCAEC proliferation.
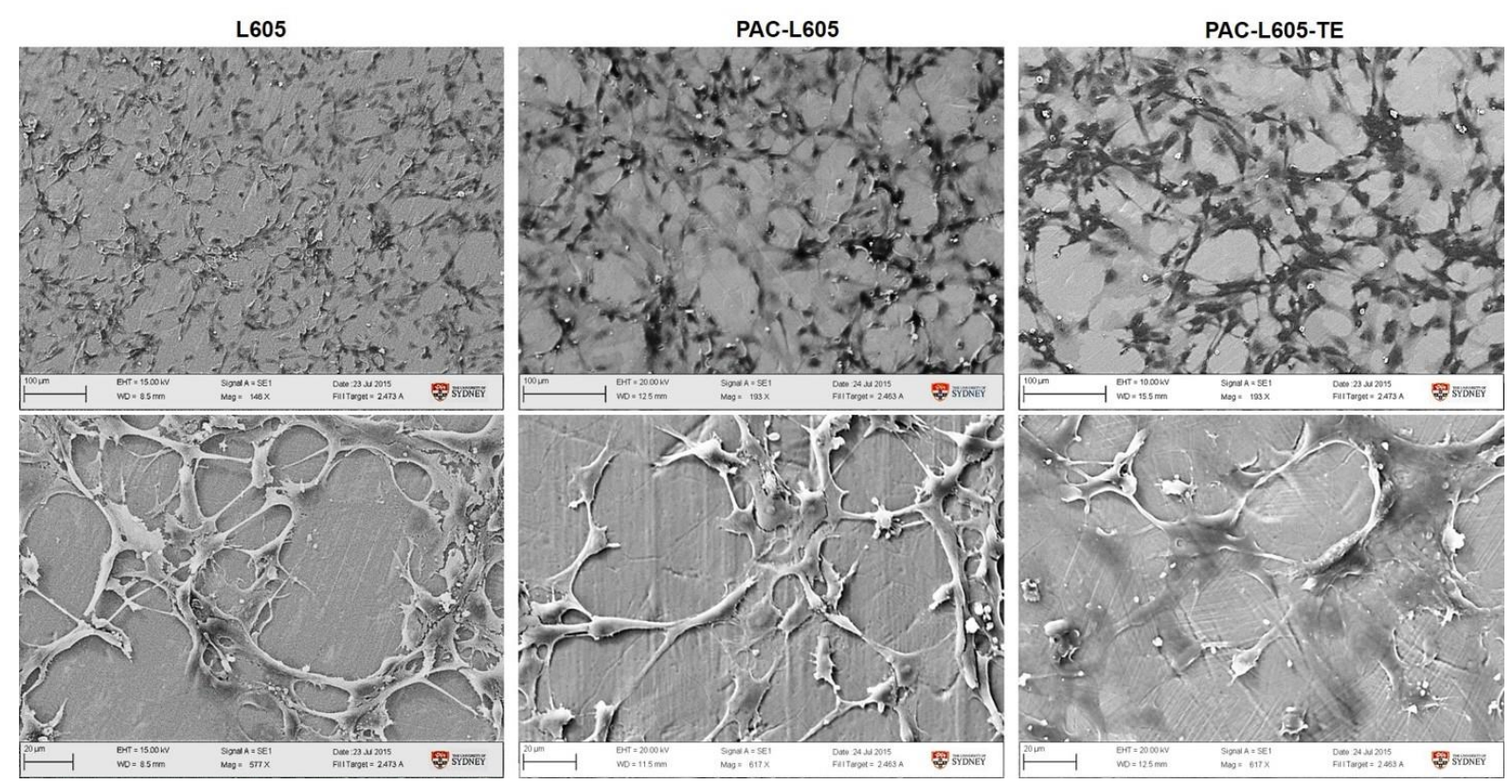

Figure 5: HCAECs on alloy L605 and PAC-L605 show more spindle projections compared to PAC-L605/TE surfaces. The PAC+TE surfaces supported confluent, homogenous HCAEC growth and improved surface-cytoskeleton attachment. 


\section{Hemocompatibility of plasma-modified biomaterials}

The presence of protein in PRP, prevented platelet and fibrin adherence to modified, hydrophilic PAC-L605 and PAC-L605/TE surfaces. Fibrins and platelets adhered on the hydrophobic, bare metal alloy L605 (Figure 6).

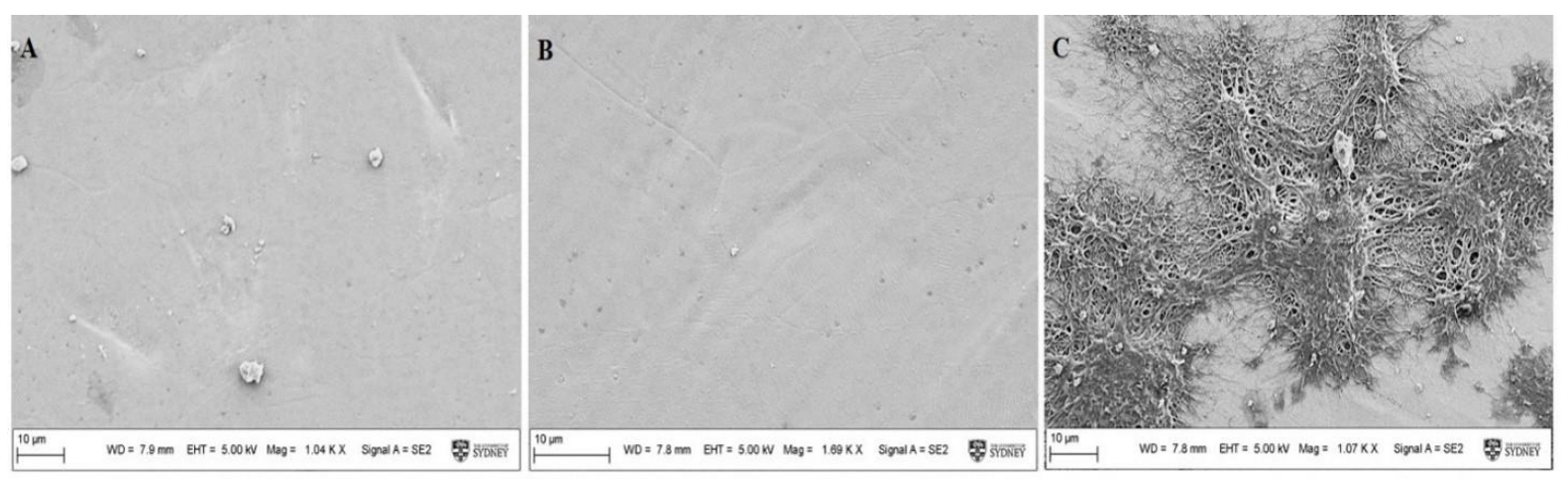

Figure 6: Hydrophilic surfaces PAC-L605 and PAC-L605/TE (A\&B) prevented protein aggregation compared to hydrophobic L605 (C), FESEM, $1.2 \mathrm{Kx}$ magnification.

The surface ageing study conducted with PRP showed sustained hemocompatibility for both PAC-L605/TE surfaces incubated with TE for 2 weeks $\left(-20^{\circ} \mathrm{C}\right)$ and overnight $\left(4^{\circ} \mathrm{C}\right)$. Hemocompatibility was retained on PAC-L605 surfaces stored air tight for 1 month. Surface platelet aggregation and fibrin clot formation was seen on alloy L605 (Figure 7 A-D).

A

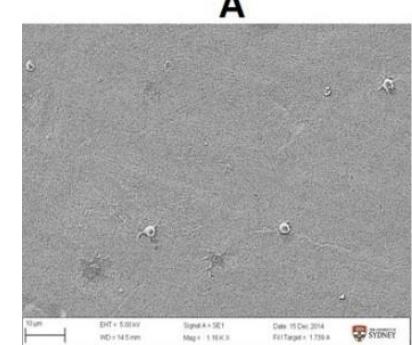

B

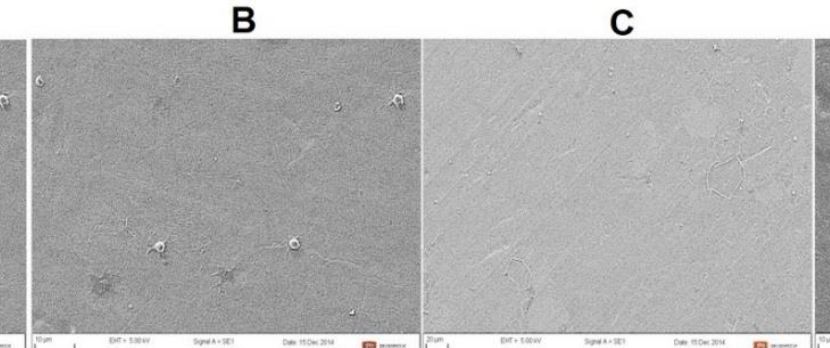

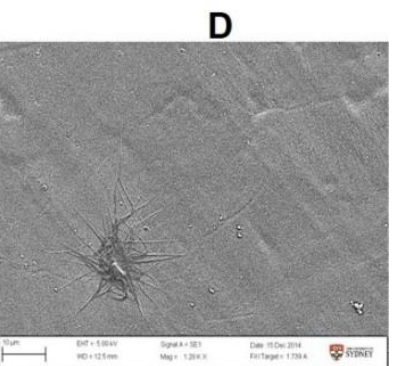

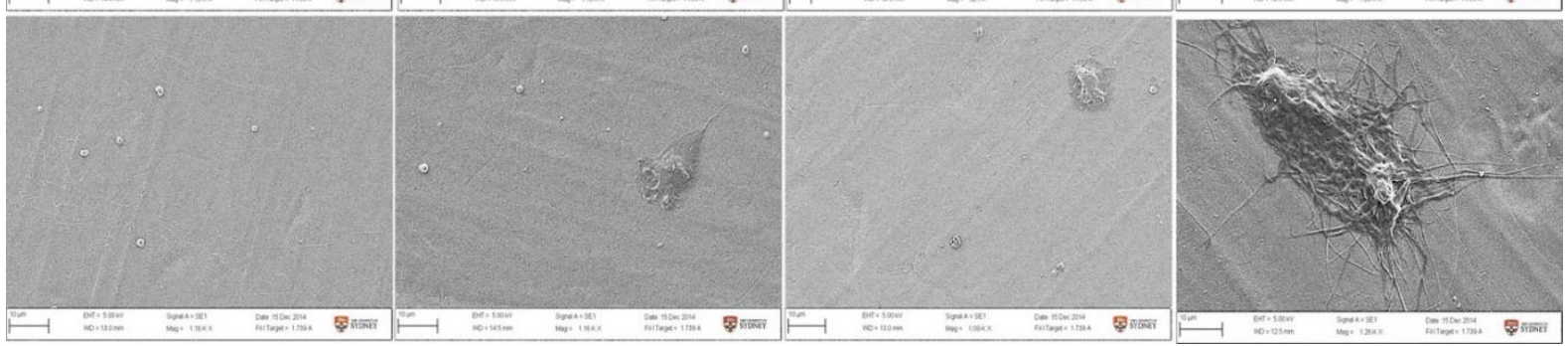

Figure 7: SEM images of the ageing study showed sustained hemocompatibility on A) PACL605/TE (2 weeks, -20 ${ }^{\circ}$ C), B) PAC-L605/TE (overnight, $4^{\circ}$ C), C) PAC-L605 (air tight, 1 month) and surface platelet/fibrin clot deposition on D) alloy L605. (1.08 Kx magnification)

Whole blood adhesion assays showed lower thrombogenicity for PAC-L605 vs. L605 within the time frame of 30,60 and 90 min flow. For optimum surface hemocompatibility assessment, the 60 min time-point was selected (Figure 8). 

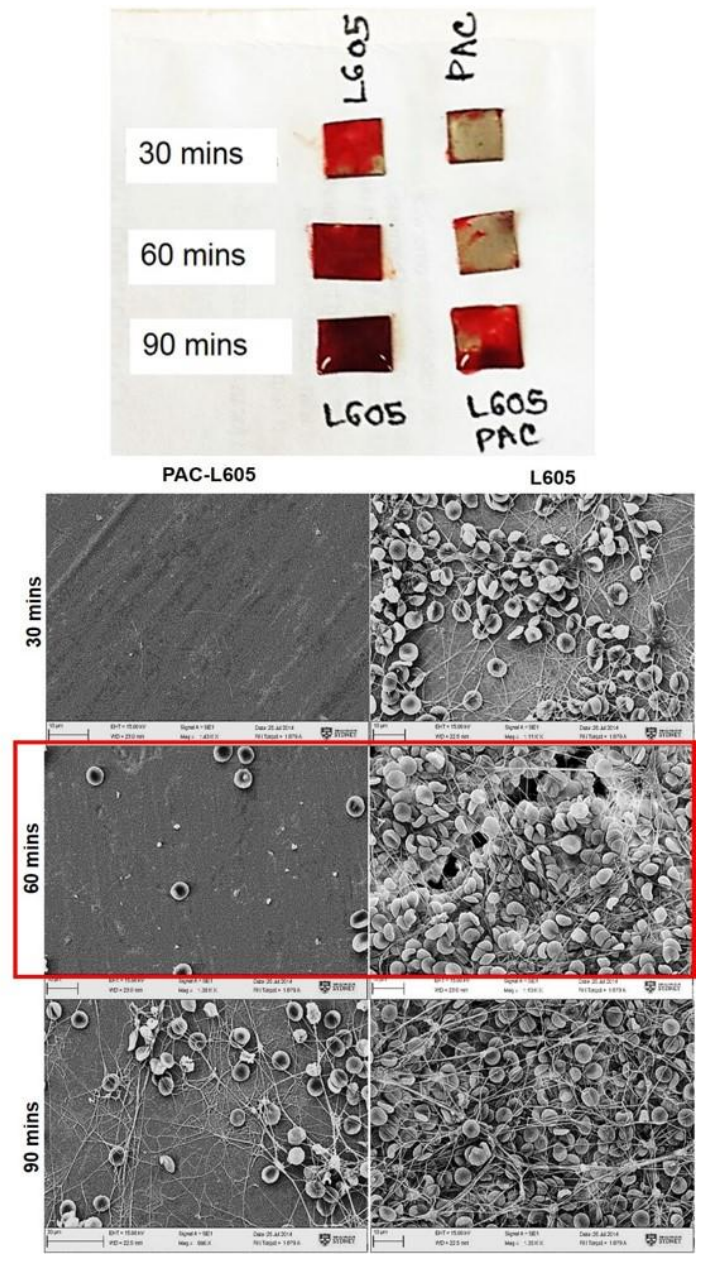

A
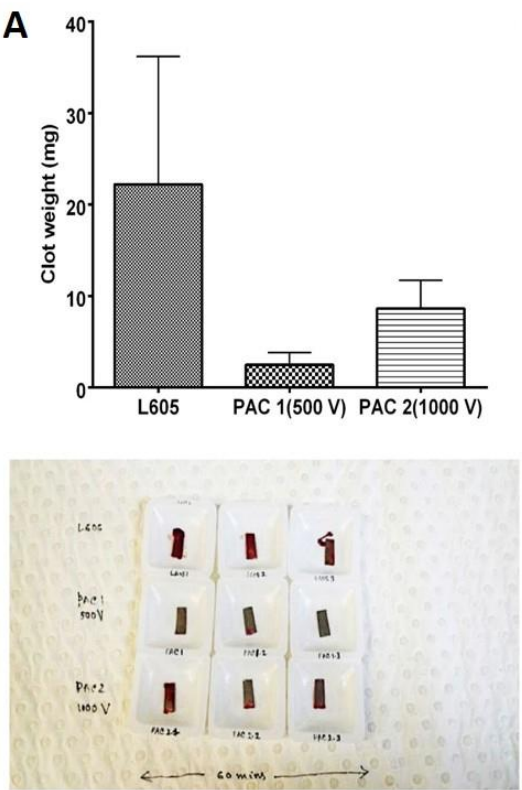

B
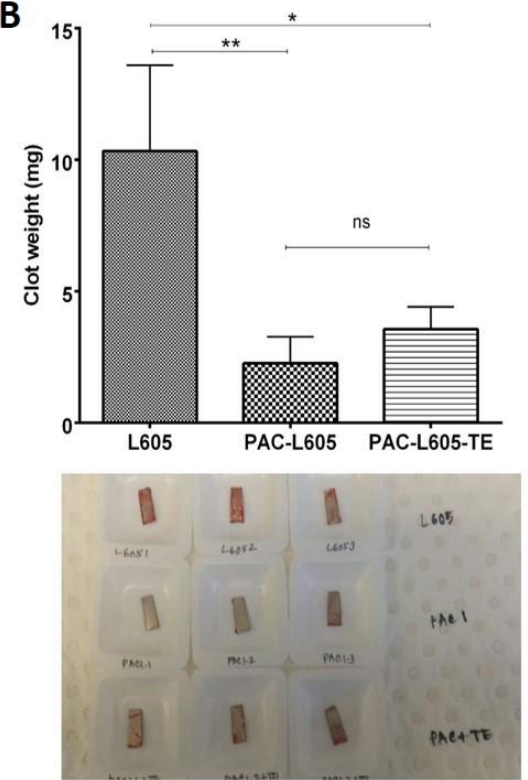

Figure 8: Comparatively lower thrombogenicity observed at 30, 60, and 90 min time points for PAC-L605 vs. L605.

Hemocompatibility under flow conditions with a modified chandler loop demonstrated lowered clot formation for PAC1-L605 vs. PAC2-L605 vs. L605 (2.5 $\pm 1.1 \mathrm{mg}$ vs. $8.63 \pm 2.5$ mg vs. $22.2 \pm 11.4 \mathrm{mg}, \mathrm{p}=0.06$, not significant) (Figure 9A).

Flow assays were repeated with PAC1-L605 recipe (hitherto referred as PAC-L605 for blood assays) vs. PAC-L605/TE vs. L605, 1 week post modification $(2.26 \pm 1.0 \mathrm{mg}$ vs. $3.56 \pm 3.6 \mathrm{mg}$ vs. $10.33 \pm 3.3 \mathrm{mg}, \mathrm{p}<0.05)$. The presence of tropoelastin did not contribute to significantly lowered clot formation compared to PAC surfaces alone (Figure 9B)

Five months post-modification flow assays were repeated with PAC-L605 vs. L605 (7.16 $\pm 3.5 \mathrm{mg}$ vs. $25.16 \pm 6.66 \mathrm{mg}, \mathrm{p}<0.05)$. As with static blood assays, hemocompatibility was retained with ageing (Figure 9C).

Figure 9: Hemocompatibility under flow conditions A) thrombogenicity among PAC recipes $1 \& 2$ compared to $L 605$ B) clot formation reduced for plasma-modified surfaces with/without TE compared to L605 C) surface hemocompatibility retained 5 months after storage for PACL605 vs. L605. 
Surface fibrinogen visualized after 60 min chandler loop flow assays, indicated lower fibrinogen staining uptake area on PAC-L605 vs. L605 $\left(481.40 \pm 263.92 \mu \mathrm{m}^{2}\right.$ vs. $1451.82 \pm 867.83 \mu \mathrm{m}^{2}$ ). Increased standard deviation of surface fibrinogen area indicated inconsistent deposition (Figure 10).
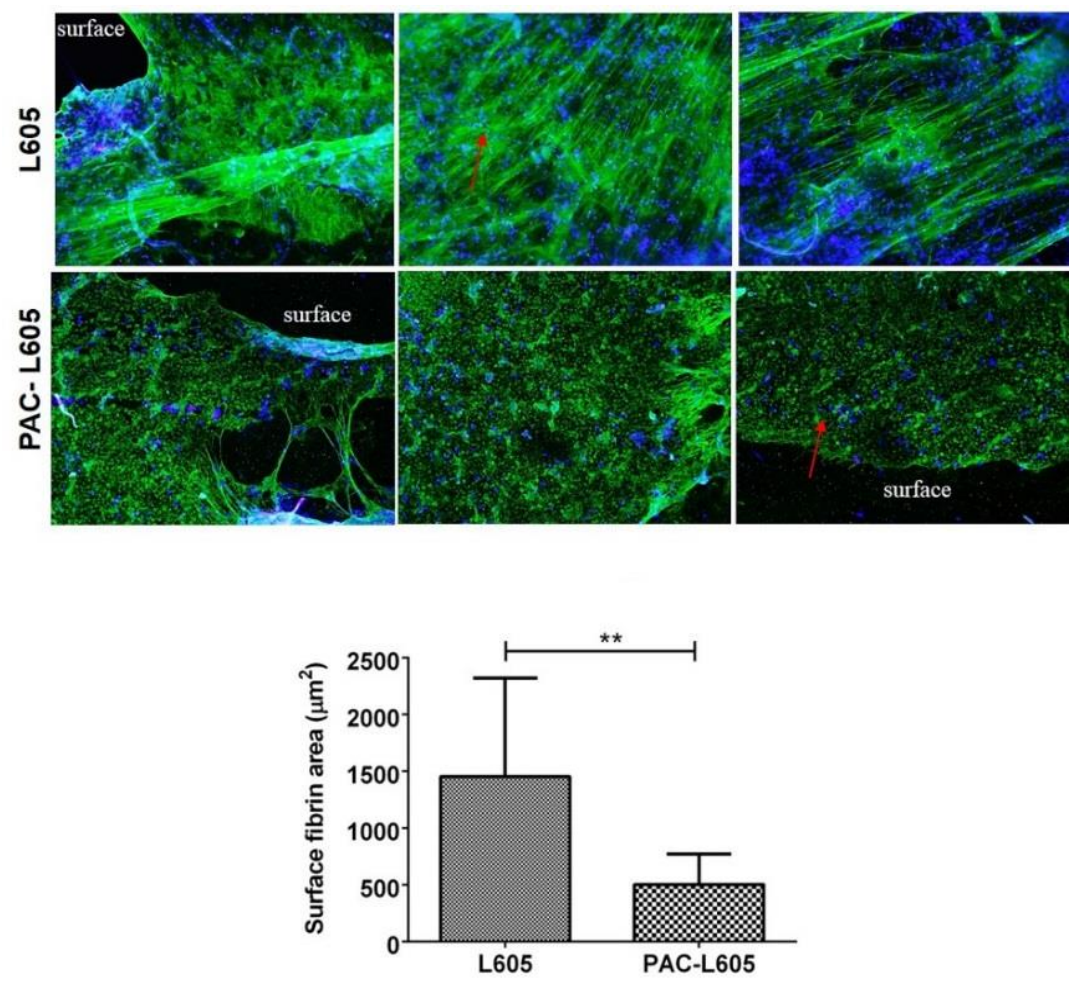

Figure 10: Surface fibrinogen deposition (red arrows) visualized with fibrinogen-Alexa Flour 488 and DAPI (nuclei), on L605 vs. PAC-L605. (10x magnification, $200 \mu \mathrm{m}$ scale bar). Area calculated with Image Pro Premier software (Media Cybernetics, USA). 


\section{Plasma biomarker activation after blood-material contact}

Plasma isolated after 60 min blood-material contact for ELISA, showed significantly lowered biomarkers of TAT for PAC-L605 vs. L605 $(7.22 \pm 1.33 \mathrm{ng} / \mathrm{ml}$ vs. $15.93 \pm 2.55$ $\mathrm{ng} / \mathrm{ml}, \mathrm{p}=0.002$ ) (Figure $11 \mathrm{~A}$ ). Similar results were observed for $\beta-\mathrm{TG}(16.61 \pm 3.33 \mathrm{ng} / \mathrm{ml}$ vs. $27.16 \pm 3.75 \mathrm{ng} / \mathrm{ml}, \mathrm{p}=0.025)$ (Figure $11 \mathrm{~B}$ ), soluble-P selectin $(4.87 \pm 0.07 \mathrm{ng} / \mathrm{ml}$ vs. $10.575 \pm 0.20 \mathrm{ng} / \mathrm{ml}, \mathrm{p}=0.013)$ (Figure 11C) and SC5b-9 $(98.18 \pm 21.88 \mathrm{ng} / \mathrm{ml}$ vs. $120.27 \pm 15.05 \mathrm{ng} / \mathrm{ml}, \mathrm{p}=0.032$, high control $113.66 \pm 1.41 \mathrm{ng} / \mathrm{ml}$ and low control $34.20 \pm 1.98 \mathrm{ng} / \mathrm{ml}$ ) (Figure 11D). Biomarker PMN-elastase was not significantly different for PAC-L605 vs. L605 (3.26 $\pm 0.26 \mathrm{ng} / \mathrm{ml}$ vs. $2.72 \pm 0.45 \mathrm{ng} / \mathrm{ml}, \mathrm{p}=0.149$, high control $10.67 \pm 2.9 \mathrm{ng} / \mathrm{ml}$ and low control $1.19 \pm 0.41 \mathrm{ng} / \mathrm{ml}$ ) (Figure 11E). For consistency, all biomarker concentrations were graphed in their original values (Figure 11).

Final concentrations for PAC-L605 vs. L605 after x dilution factor, are noted within parentheses for biomarkers sP-selectin (1:30 dilution; $146.19 \pm 2.1 \mathrm{ng} / \mathrm{mL}$ vs. $317.25 \pm 6$ $\mathrm{ng} / \mathrm{mL}$ ), SC5b-9 (1:10 dilution; $981.91 \pm 218.84 \mathrm{ng} / \mathrm{ml}$ vs. $1202.77 \pm 150.53 \mathrm{ng} / \mathrm{ml}$, high control $1136.6 \pm 14.16 \mathrm{ng} / \mathrm{ml}$ and low control $342.0 \pm 19.80 \mathrm{ng} / \mathrm{ml}$ ) and PMN elastase (1:100 dilution; $272.75 \pm 45.17 \mathrm{ng} / \mathrm{ml}$ vs. $326.84 \pm 26.03 \mathrm{ng} / \mathrm{ml}$, high control $1067.52 \pm 296.83 \mathrm{ng} / \mathrm{ml}$ and low control $119.66 \pm 40.82 \mathrm{ng} / \mathrm{ml}$ ).

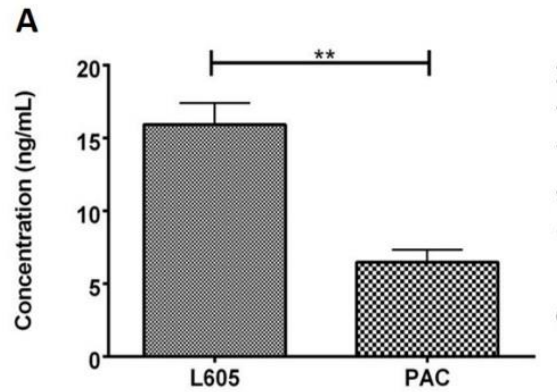

D

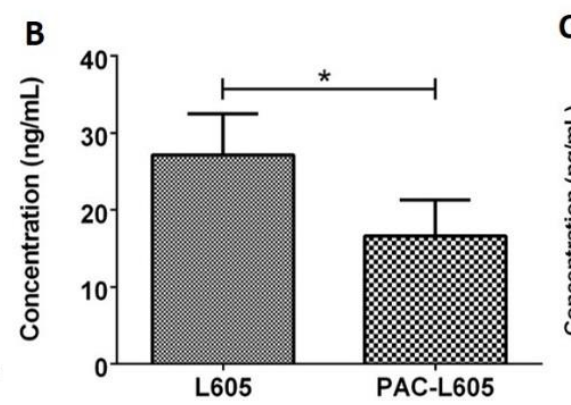

$\mathbf{E}$

\section{C}

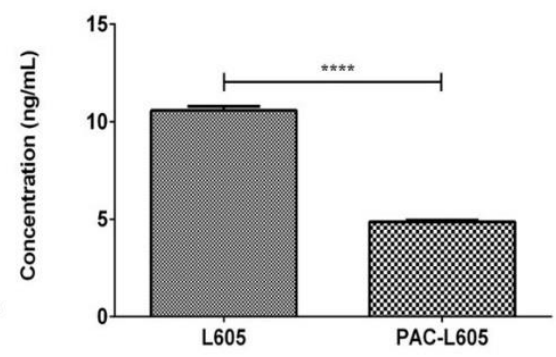

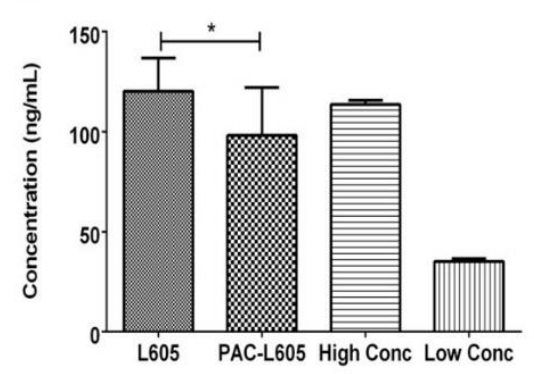

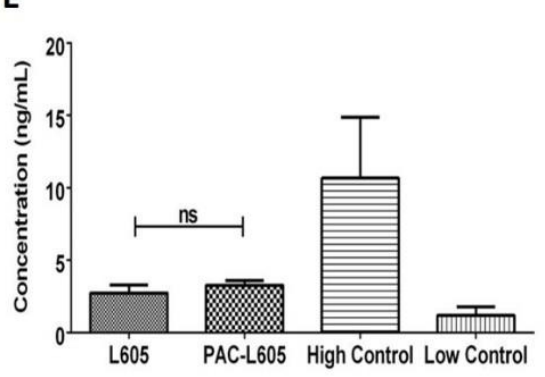

Figure 11: ELISA quantification of biomarkers after blood-material contact for PAC-L605 vs. L605 A) TAT (no dilution, $p=0.002$ ), $B) \beta$-TG (no dilution, $p=0.025), C$ ) $s P$-selectin $(1: 30$ dilution, $p=0.013), D) S C 5 b-9$ (1:10 dilution, $p=0.032)$ and $E$ ) PMN elastase (1:100 dilution, $p=0.149$ ) 
bioRxiv preprint doi: https://doi.org/10.1101/042770; this version posted March 9, 2016. The copyright holder for this preprint (which was not certified by peer review) is the author/funder, who has granted bioRxiv a license to display the preprint in perpetuity. It is made available under aCC-BY-NC-ND 4.0 International license.

\section{Discussion}

The salient findings of this study, for the previously characterized, plasma-modified PAC-L605 surface are:

1. Plasma-based surface modification allows covalent binding of tropoelastin (TE) in its native conformation.

2. Surface assisted endothelialization at cell-material interface, promotes healthy anchorage of cell cytoskeleton to material for homogenous proliferation.

3. Improved hemocompatibility. Reduced clot formation, fibrinogen deposition and reduced plasma biomarkers of coagulation, complement and platelet activity.

4. Surface biofunctionalization retained with age/time.

The data demonstrates biofunctionalization of plasma-modified surfaces in vitro, for vascular compatibility at the artery-stent material interface. The unique, controlled, covalent protein binding capacity on PAC was due to the presence of surface free radicals (Bilek et al. 2011, Waterhouse et al. 2010). However, covalently bound protein surfaces PAC-L605/TE, did not significantly improve endothelialization or hemocompatibility compared to PAC-L605 surfaces alone.

A common technique for clinical engineering biomimetic microsystems is isotropic material surface development with nanoscale/micron roughness to facilitate cell anchorage and growth (Huh et al. 2013, Place, Evans, and Stevens 2009). The cell cytoskeleton is theorized to play an integral role for coordinated attachment to a substrate (Ingber 1993). The SEM and fluorescent images obtained were limited, as they were a 2-dimensional representation of 3-D cell-material organization. However, results indicated assisted, anchorage dependent, cell spreading and proliferation on PAC2-L605 surfaces, with or without TE. Tissue engineering surfaces that mimic physiological environment for biomimicry are one of the most basic principles of biological design.

The in vitro model to assess hemocompatibility is an over-simplification of a very complex physiological system (Gaamangwe et al. 2015). The modified chandler loop system was based on previous experimental standardizations (Gaamangwe et al. 2015, Gardner 1974). Practically, hemodynamics play a quantitative role between stent implantation and thrombosis in vivo (Foin et al. 2014), and should be taken into consideration during simulations in vitro.

Under physiological conditions of static and flow blood assays, platelets aggregate together by thin fibrin strands to form thrombi on hydrophobic L605 in contrast to hydrophilic PAC-L605 surfaces. Similar results were observed with amphiphilic fibrinogen aggregates on L605 compared to PAC-L605. Hemocompatibility of modified surfaces (with or without tropoelastin), during flow and static blood assays, were retained after oxidation/ageing.

The concentration of biomarkers quantified, depend on protein-material interaction during exposure to whole blood. Predominant proteins within extracellular matrix (ECM); albumin, immunoglobulin (IgG), fibrinogen, factor XII and high molecular weight kininogen (HMWK) interact with material surface in a phenomenon termed 'Vroman effect' (Wilson et al. 2005). Accordingly, hydrophilic surfaces displace proteins to create a high surface protein turnover rate at material interface, whereas proteins on hydrophobic surfaces do not displace. Instead, surface proteins undergo conformational changes on hydrophobic surfaces, form fibrinogen aggregates, and trigger activation of 
biomarkers (Vroman and Adams 1969). Biochemical events occurring after bloodmaterial contact to trigger activation of biomarkers, quantified herein, are summarized (Figure 12).

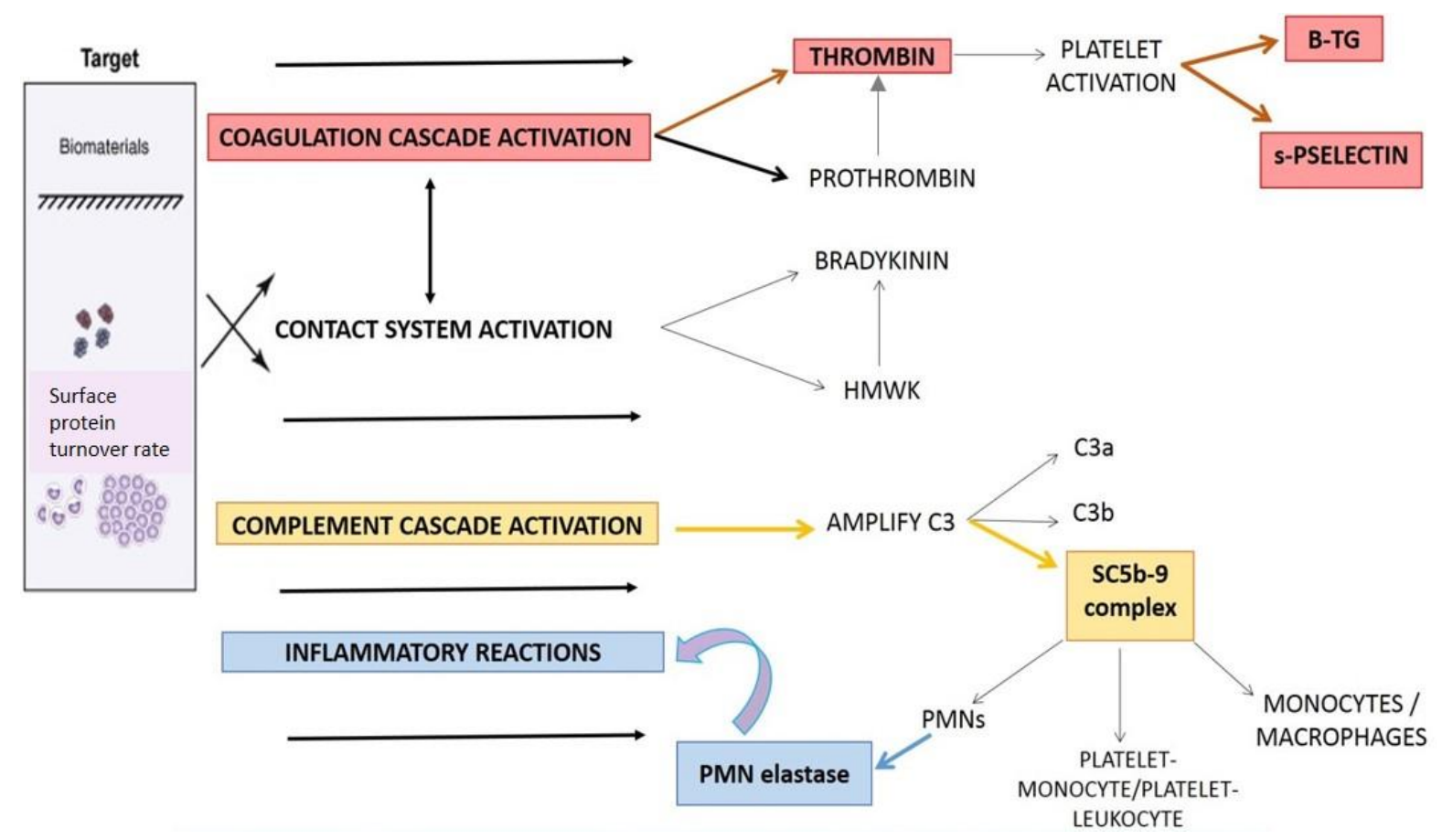

Figure 12: A simple schematic outlining the biochemical pathways activated during bloodbiomaterial contact. The highlighted biomarkers were quantified with ELISA tests in this study.

\section{Conclusion}

We investigated biofunctionalization of a previously characterized, plasma-modified, cobalt chromium alloy PAC-L605. Initial studies showed optimum endothelialization for PAC recipe 2 and optimum hemocompatibility for PAC recipe 1. All PAC surfaces covalently bound tropoelastin (TE) compared to L605, but this did not markedly improve biofunctionalization of PAC. With age, biofunctionalization of PAC surfaces retained. For further investigations we propose an optimized recipe of PAC $(\mathrm{C}-1, \mathrm{~N}-10, \mathrm{t}=10 \mathrm{~min}, 500$ $\mathrm{V}$ ), which may simultaneously promote both endothelialization and hemocompatibility. Tests in accordance to ISO 10993-4, for biological evaluation of medical devices using PAC recipe 1 vs. L605, indicated comparatively superior hemocompatibility for PAC. The preliminary biofunctionalization study, optimized plasma-activated coating (PAC) on a cobalt chromium material and optimized ISO-109934 recommended in vitro biological tests, prior to PAC deposition on a cobalt chromium stent platform for further research. 
bioRxiv preprint doi: https://doi.org/10.1101/042770; this version posted March 9,2016 . The copyright holder for this preprint (which was

\section{Acknowledgements}

Manuscript originally produced as thesis chapters ('Plasma based biofunctionalization of cobalt chromium alloy L605' and 'Biological evaluation of medical devices; selection of tests for interactions with blood') for Doctor of Philosophy (PhD) Medicine, Sydney Medical School, University of Sydney - September 2015. Initial research work presented at the Atherosclerosis, Thrombosis and Vascular Biology (ATVB) Scientific conference, American Heart Association, San Francisco, CA, USA, May 2015 (DOI:10.7490/f1000research.1111024.1). The author acknowledges -

Applied Plasma Physics Department of the University of Sydney, for plasma-activated coating (PAC) development.

The Australian Center for Microscopy and Microanalysis (ACMM), University of Sydney, for research and technical support; Mr. Steven Moody (SEM Specialist), Dr. Patrick Trimby (SEM Specialist) and Miss Naveena Gokoolparsadh (Biological Specimen Preparation Specialist)

The Heart Research Institute, Newtown, Tissue Culture lab facilities, research and technical support; Pat Pisansarakit

Study funded by the National Health and Medical Research Council (APP1033079 and APP1039072) and PhD tenure: Elizabeth and Henry Hamilton-Browne Scholarship, Faculty of Medicine, Sydney Medical School.

\section{References}

Alhejily, Wesam A., and E. Magnus Ohman. 2012. "Repeat Revascularization After PCI: Are We Reinventing the Wheel or Redefining Achilles' Heel?" Circulation: Cardiovascular Interventions 5 (6):746-747. doi: 10.1161/circinterventions.112.974956.

Bilek, M. M. M., D. V. Bax, A. Kondyurin, Y. B. Yin, N. J. Nosworthy, K. Fisher, A. Waterhouse, A. S. Weiss, C. G. dos Remedios, and D. R. McKenzie. 2011. "Free radical functionalization of surfaces to prevent adverse responses to biomedical devices." Proceedings of the National Academy of Sciences of the United States of America 108 (35):14405-14410. doi: 10.1073/pnas.1103277108.

Coutinho, Daniela, Pedro Costa, Nuno Neves, Manuela E. Gomes, and Rui L. Reis. 2011. "Micro- and Nanotechnology in Tissue Engineering." In Tissue Engineering: From Lab to Clinic, edited by Norbert Pallua and V. Christoph Suscheck, 3-29. Berlin, Heidelberg: Springer Berlin Heidelberg.

Cutlip, D. E., S. Windecker, R. Mehran, A. Boam, D. J. Cohen, G. A. van Es, P. G. Steg, M. A. Morel, L. Mauri, P. Vranckx, E. McFadden, A. Lansky, M. Hamon, M. W. Krucoff, P. W. Serruys, and Acad Res Consortium. 2007. "Clinical end points in coronary stent trials - A case for standardized definitions." Circulation 115 (17):23442351. doi: 10.1161/Circulationaha.106.685313.

Foin, N., J. L. Gutierrez-Chico, S. Nakatani, R. Torii, C. V. Bourantas, S. Sen, S. Nijjer, R. Petraco, C. Kousera, M. Ghione, Y. Onuma, H. M. Garcia-Garcia, D. P. Francis, P. Wong, C. Di Mario, J. E. Davies, and P. W. Serruys. 2014. "Incomplete Stent Apposition Causes High Shear Flow Disturbances and Delay in Neointimal Coverage as a Function of Strut to Wall Detachment Distance Implications for the 
bioRxiv preprint doi: https://doi.org/10.1101/042770; this version posted March 9, 2016. The copyright holder for this preprint (which was not certified by peer review) is the author/funder, who has granted bioRxiv a license to display the preprint in perpetuity. It is made available under aCC-BY-NC-ND 4.0 International license.

Management of Incomplete Stent Apposition." Circulation-Cardiovascular Interventions 7 (2):180-189. doi: 10.1161/Circinterventions.113.000931.

Gaamangwe, T., V. Babbar, A. Krivoy, M. Moore, and P. Kresta. 2015. "Medical Device Risk Management For Performance Assurance Optimization and Prioritization." Biomed Instrum Technol 49 (6):446-51. doi: 10.2345/0899-8205-49.6.446.

Gaamangwe, T., Peterson S.D., Gorbet M. B. 2014. "Investigating the Effect of Blood Sample Volume in the Chandler Loop Model: Theoretical and Experimental Analysis." Cardiovascular Engineering and Technology 5 (2):133-144.

Gardner, R. A. 1974. "An examination of the fluid mechanics and thrombus formation time parameters in a Chandler rotating loop system." J Lab Clin Med 84 (4):494508.

Huh, D., H. J. Kim, J. P. Fraser, D. E. Shea, M. Khan, A. Bahinski, G. A. Hamilton, and D. E. Ingber. 2013. "Microfabrication of human organs-on-chips." Nature Protocols 8 (11):2135-2157. doi: 10.1038/nprot.2013.137.

Ingber, Donald E. 1993. "Cellular tensegrity: defining new rules of biological design that govern the cytoskeleton." Journal of Cell Science 104 (3):613-627.

Jeewandara, T. M. 2016. "Bioengineering cobalt chromium cardiovascular stent biomaterial for surface enhancement and characterization." The Winnower 3. doi: $10.15200 /$ winn.145619.92147.

Jeewandara, T. M., S. G. Wise, and M. K. C. Ng. 2014. "Biocompatibility of Coronary Stents." Materials 7 (2):769-786. doi: 10.3390/ma7020769.

Malmsten, M. 1998. "Formation of adsorbed protein layers." Journal of Colloid and Interface Science 207 (2):186-199. doi: DOI 10.1006/jcis.1998.5763.

Martin, S. L., B. Vrhovski, and A. S. Weiss. 1995. "Total Synthesis and Expression in Escherichia-Coli of a Gene Encoding Human Tropoelastin." Gene 154 (2):159166. doi: Doi 10.1016/0378-1119(94)00848-M.

Nyanhongo, G.S., W. Steiner, and G.M. Gübitz. 2011. Biofunctionalization of Polymers and their Applications: Springer Berlin Heidelberg.

Place, Elsie S., Nicholas D. Evans, and Molly M. Stevens. 2009. "Complexity in biomaterials for tissue engineering." Nat Mater 8 (6):457-470. doi: http://www.nature.com/nmat/journal/v8/n6/suppinfo/nmat2441 S1.html.

Prentner, S., D. M. Allen, L. Larcombe, S. Marson, K. Jenkins, and M. Saumer. 2010. "Effects of channel surface finish on blood flow in microfluidic devices." Microsystem Technologies-Micro-and Nanosystems-Information Storage and Processing Systems 16 (7):1091-1096. doi: 10.1007/s00542-009-1004-1.

Seyfert, U. T., V. Biehl, and J. Schenk. 2002. "In vitro hemocompatibility testing of biomaterials according to the ISO 10993-4." Biomolecular Engineering 19 (26):91-96. doi: Pii S1389-0344(02)00015-1

Doi 10.1016/S1389-0344(02)00015-1.

Vroman, L., and A. L. Adams. 1969. "Identification of rapid changes at plasma-solid interfaces." J Biomed Mater Res 3 (1):43-67. doi: 10.1002/jbm.820030106.

Waterhouse, A., D. V. Bax, S. G. Wise, Y. B. Yin, L. L. Dunn, G. C. Yeo, M. K. C. Ng, M. M. M. Bilek, and A. S. Weiss. 2011. "Stability of a Therapeutic Layer of Immobilized Recombinant Human Tropoelastin on a Plasma-Activated Coated Surface." Pharmaceutical Research 28 (6):1415-1421. doi: 10.1007/s11095-010-0327-z.

Waterhouse, A., Y. B. Yin, S. G. Wise, D. V. Bax, D. R. McKenzie, M. M. M. Bilek, A. S. Weiss, and M. K. C. Ng. 2010. "The immobilization of recombinant human tropoelastin on metals using a plasma-activated coating to improve the biocompatibility of 
coronary stents." Biomaterials 31 (32):8332-8340. doi:

10.1016/j.biomaterials.2010.07.062.

Wilson, C. J., R. E. Clegg, D. I. Leavesley, and M. J. Pearcy. 2005. "Mediation of biomaterial-cell interactions by adsorbed proteins: a review." Tissue Eng 11 (12):1-18. doi: 10.1089/ten.2005.11.1.

Wozniak, M. A., K. Modzelewska, L. Kwong, and P. J. Keely. 2004. "Focal adhesion regulation of cell behavior." Biochimica Et Biophysica Acta-Molecular Cell Research 1692 (2-3):103-119. doi: 10.1016/j.bbamcr.2004.04.007.

Yin, Y. B., S. G. Wise, N. J. Nosworthy, A. Waterhouse, D. V. Bax, H. Youssef, M. J. Byrom, M. M. M. Bilek, D. R. McKenzie, A. S. Weiss, and M. K. C. Ng. 2009. "Covalent immobilisation of tropoelastin on a plasma deposited interface for enhancement of endothelialisation on metal surfaces." Biomaterials 30 (9):1675-1681. doi: 10.1016/j.biomaterials.2008.11.009. 


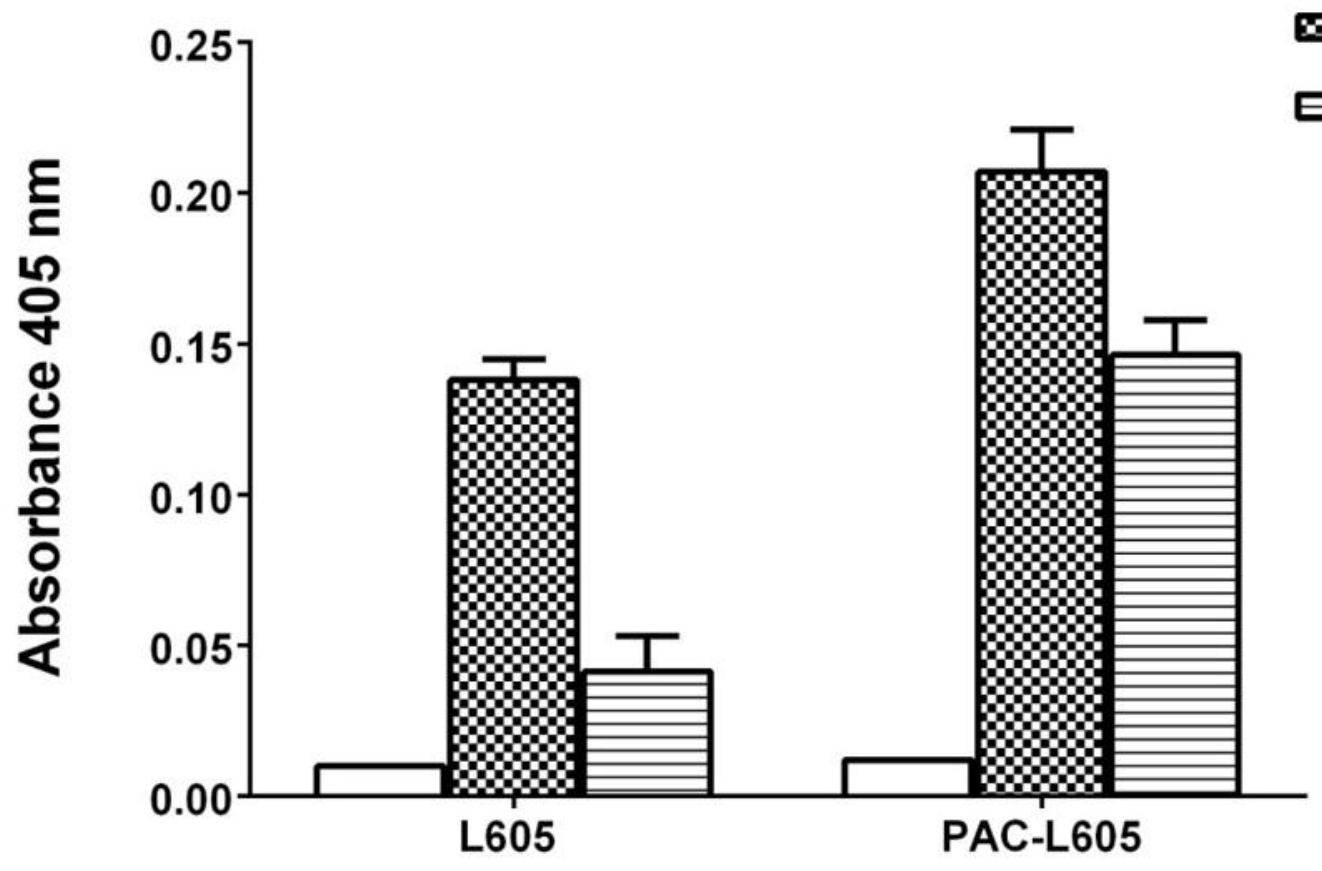

$\square$-TE

$\infty$ TE-SDS

అ $\mathrm{TE}+\mathrm{SDS}$ 
$\longleftarrow-3$ day
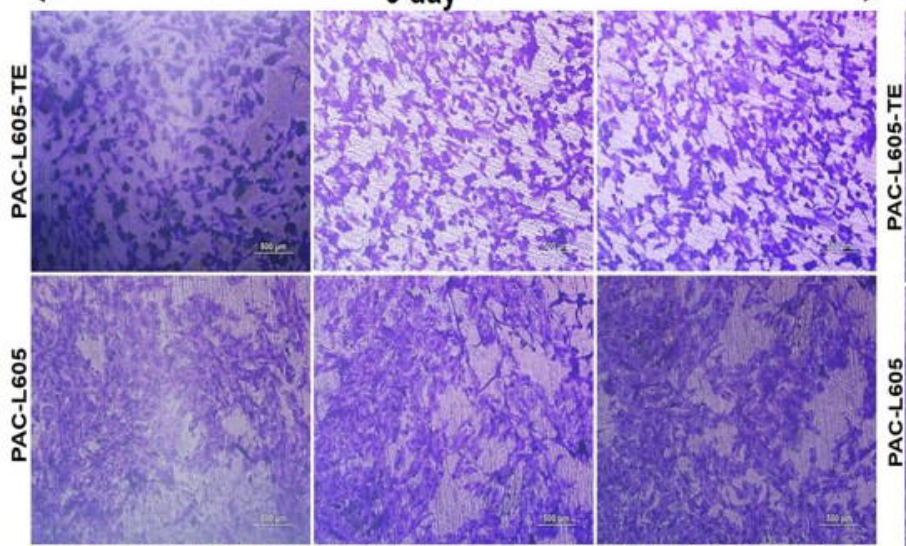

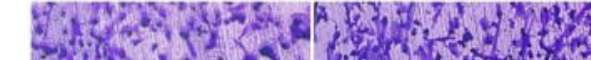

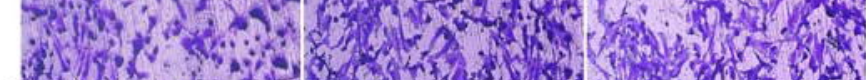

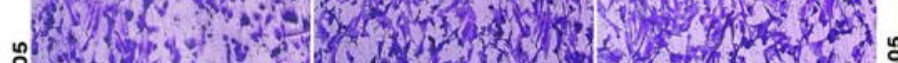

¿5.

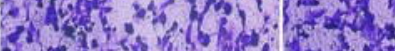

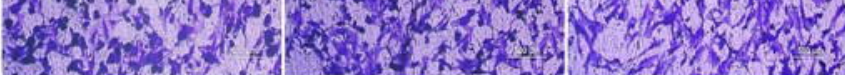

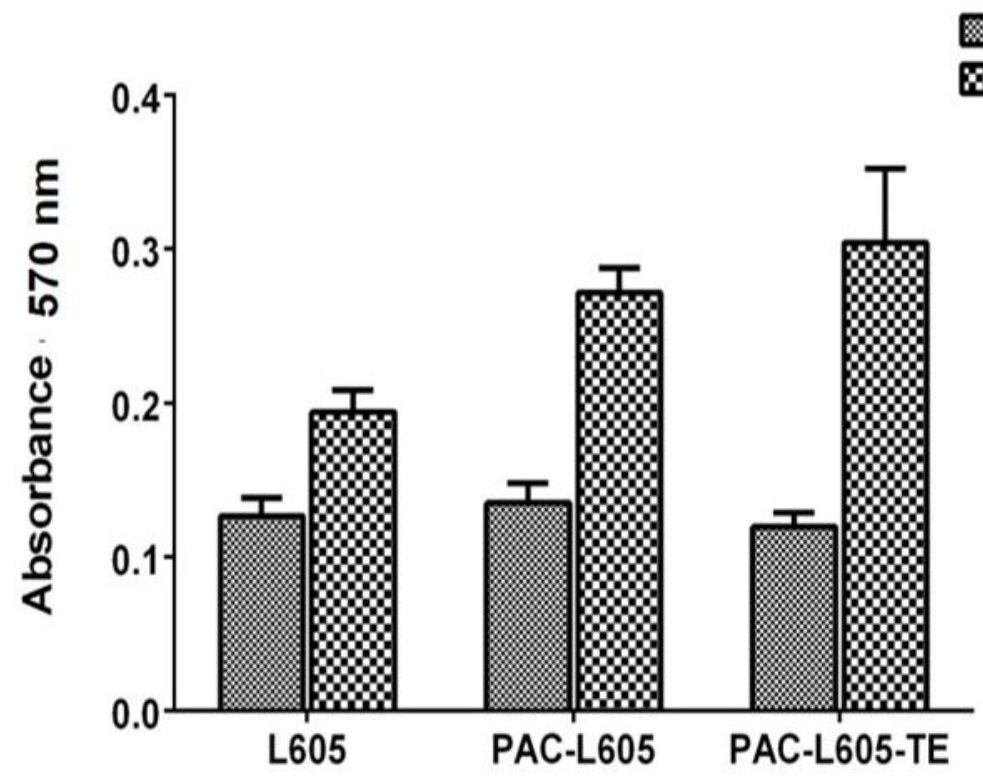

3 day

$\mathbf{x} 5$ day 

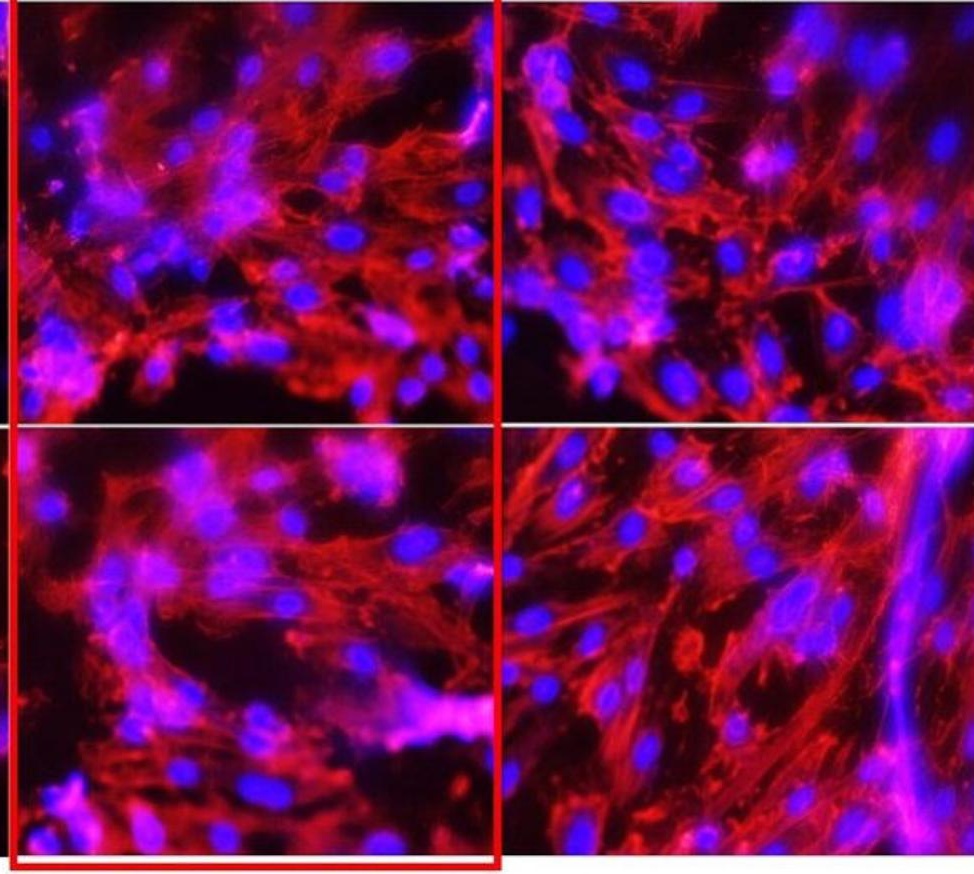


\section{F-actin}

Merge

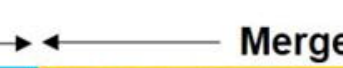

$\longleftarrow$ vWF PAC- L605
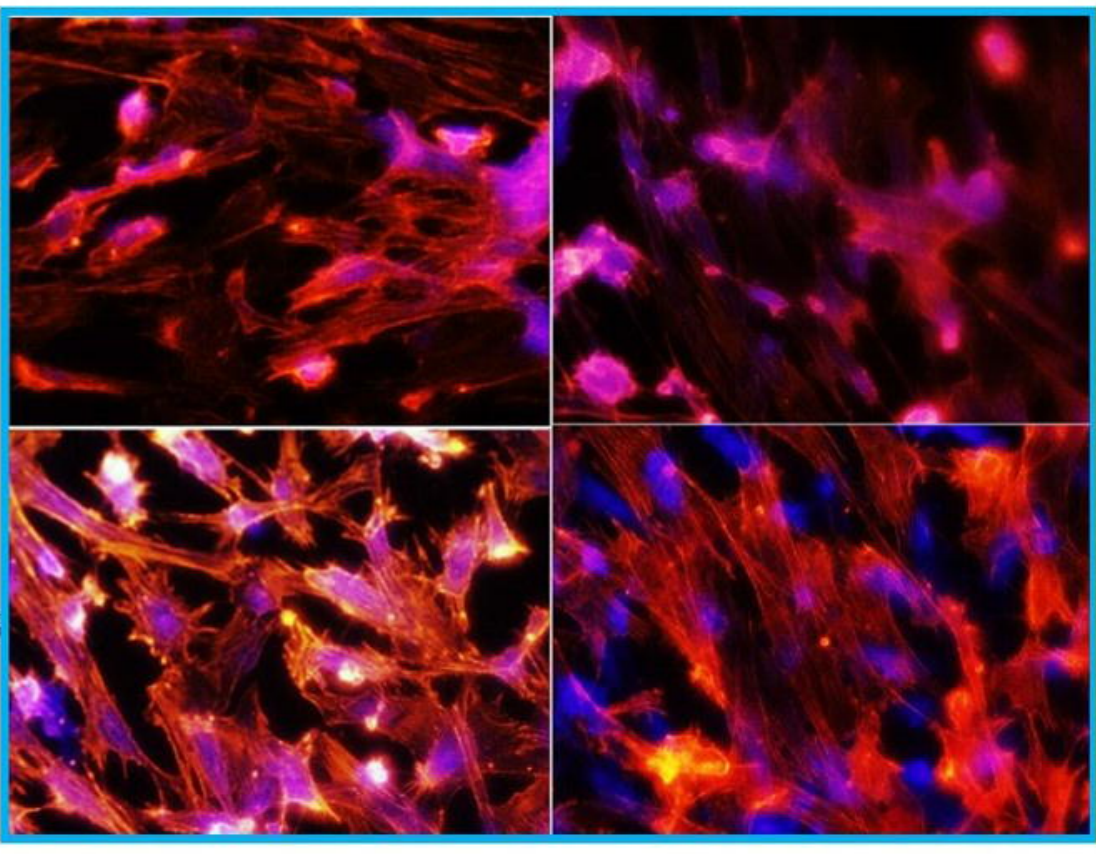

DAPI-TRITC

Merge

Alexafluor 

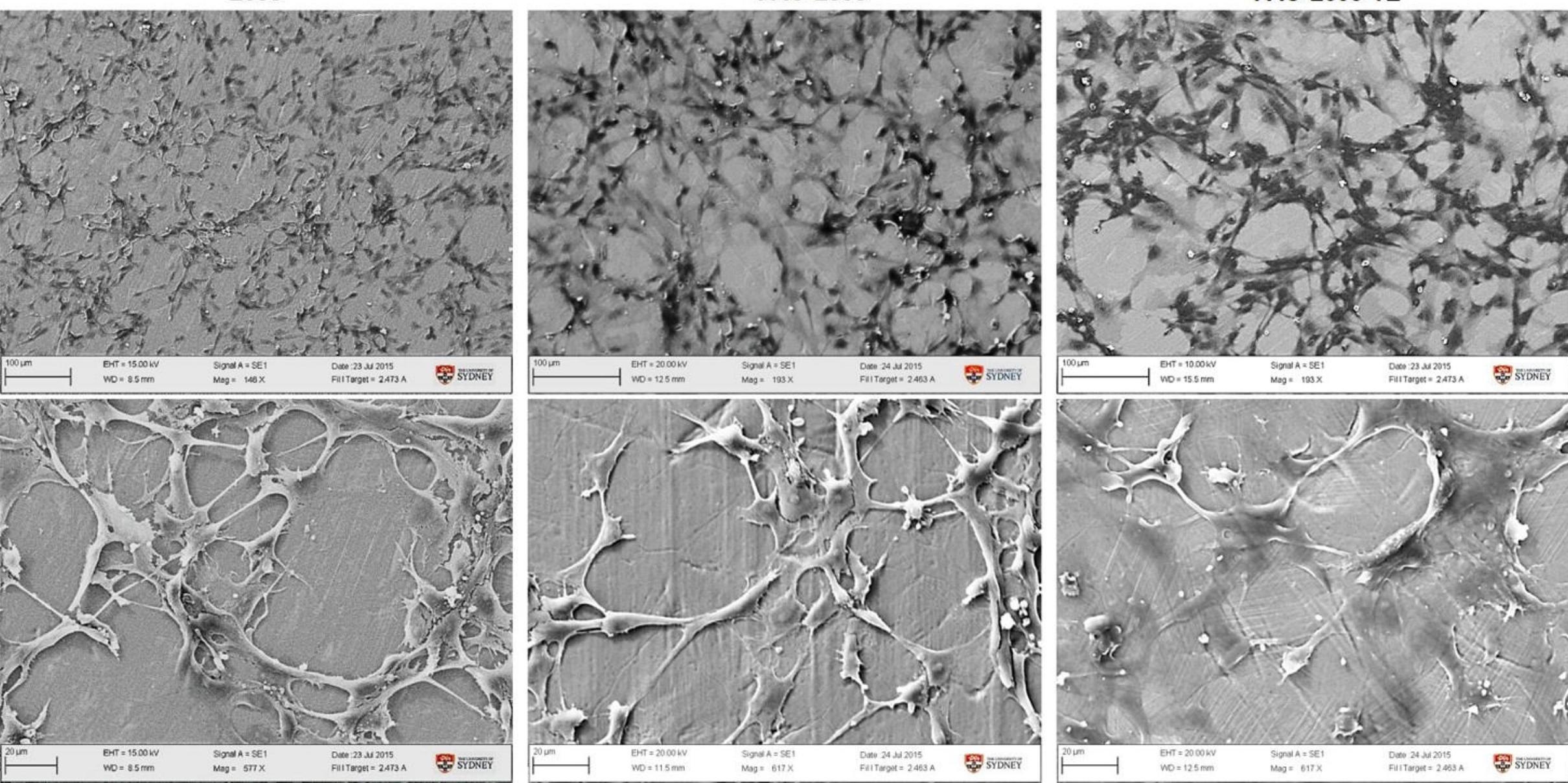


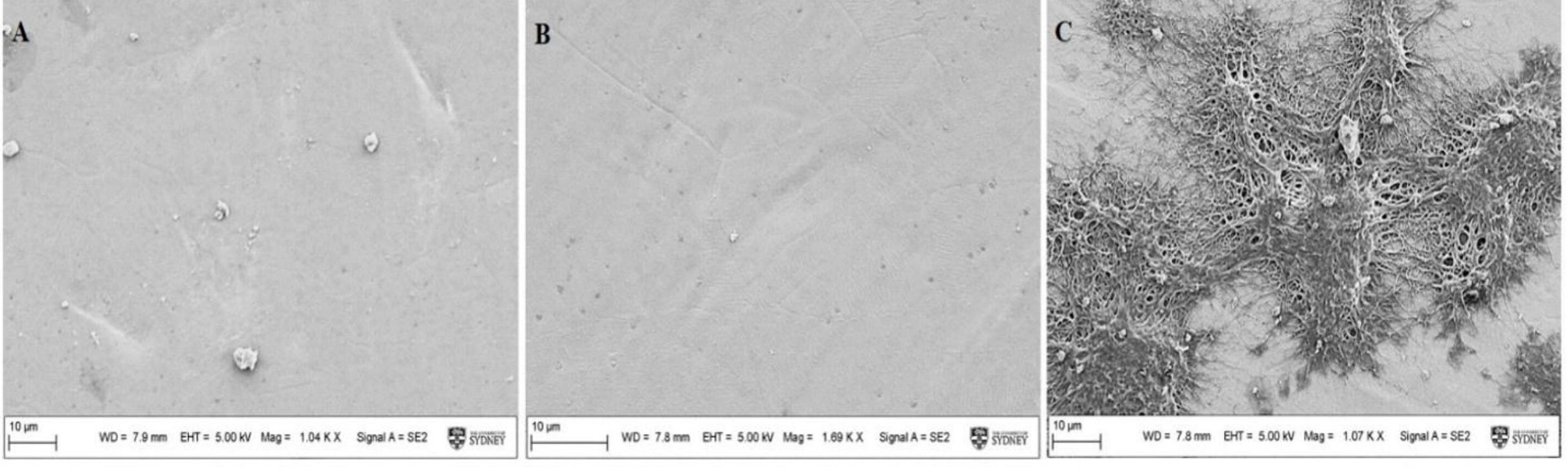




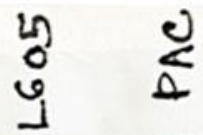

30 mins
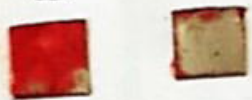

60 mins
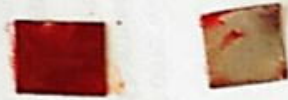

90 mins
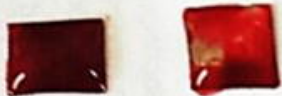

$\angle 605$

\section{L605 PAC}

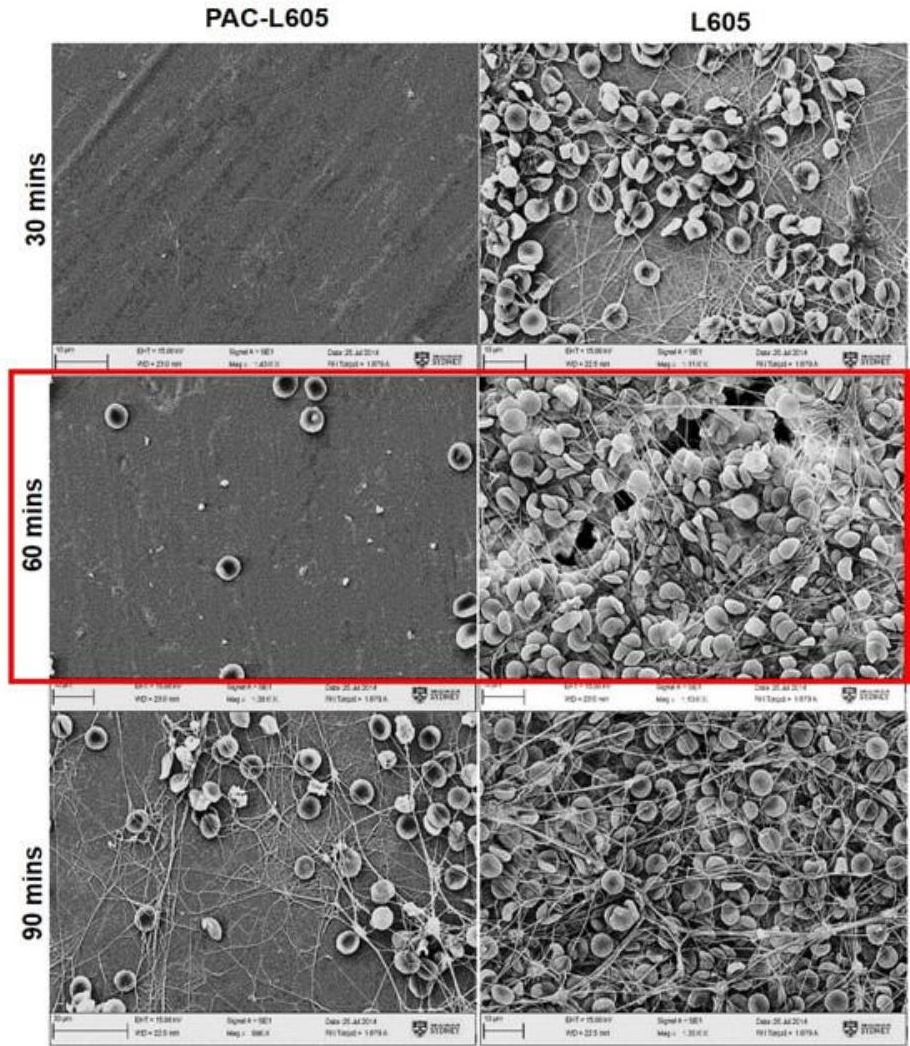



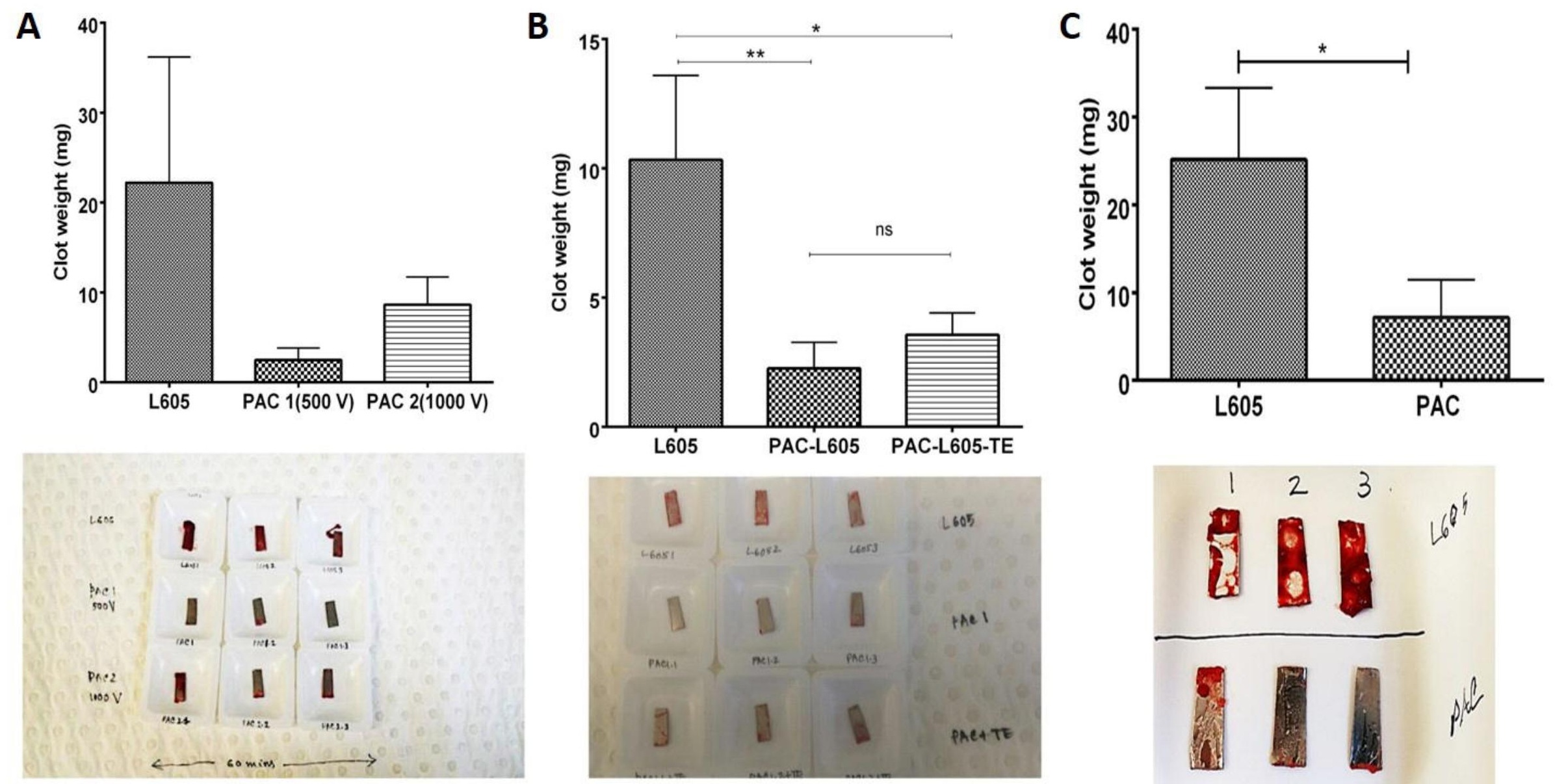


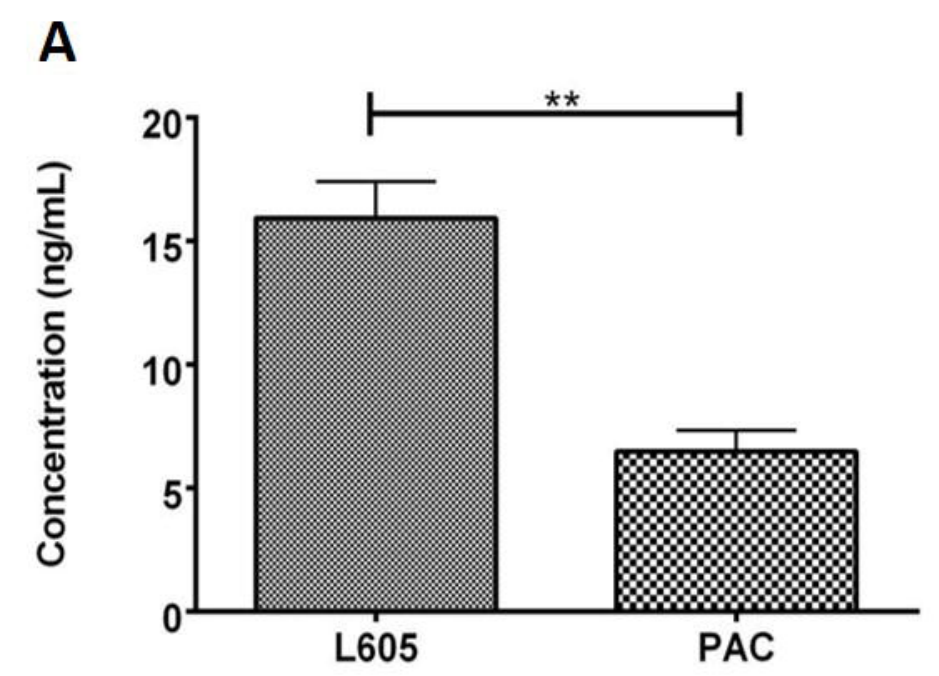

D

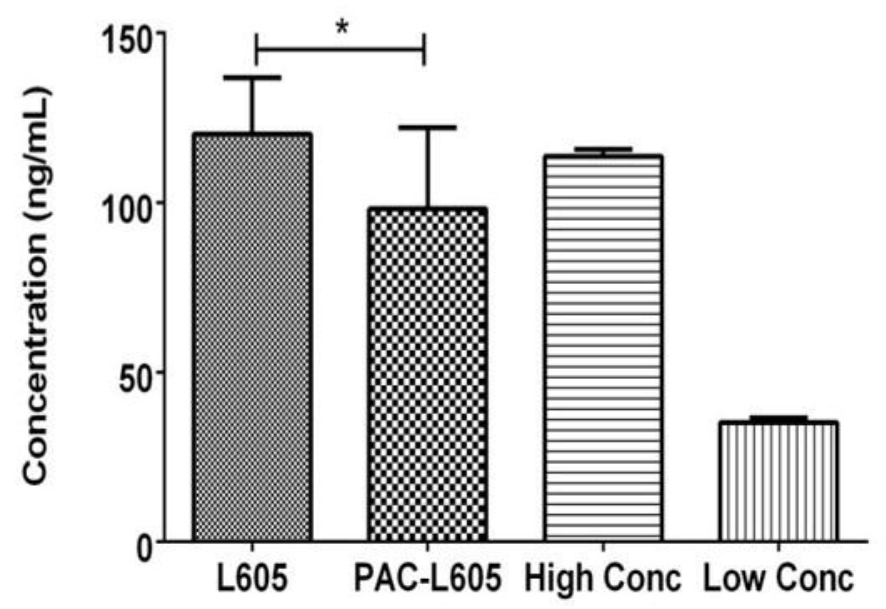

\section{B}

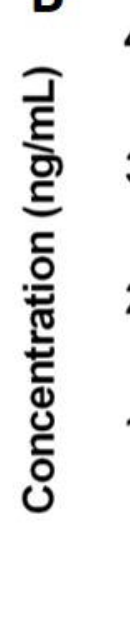

C

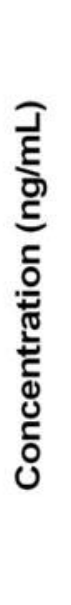

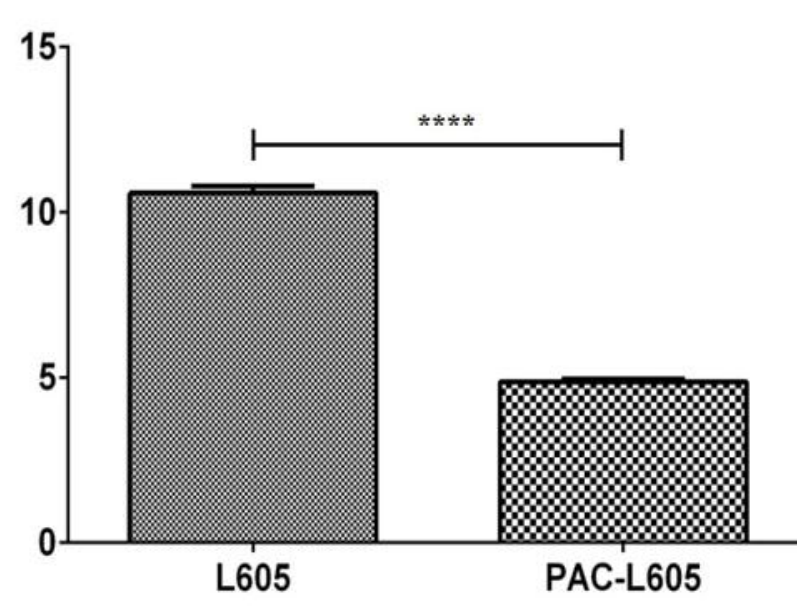

E

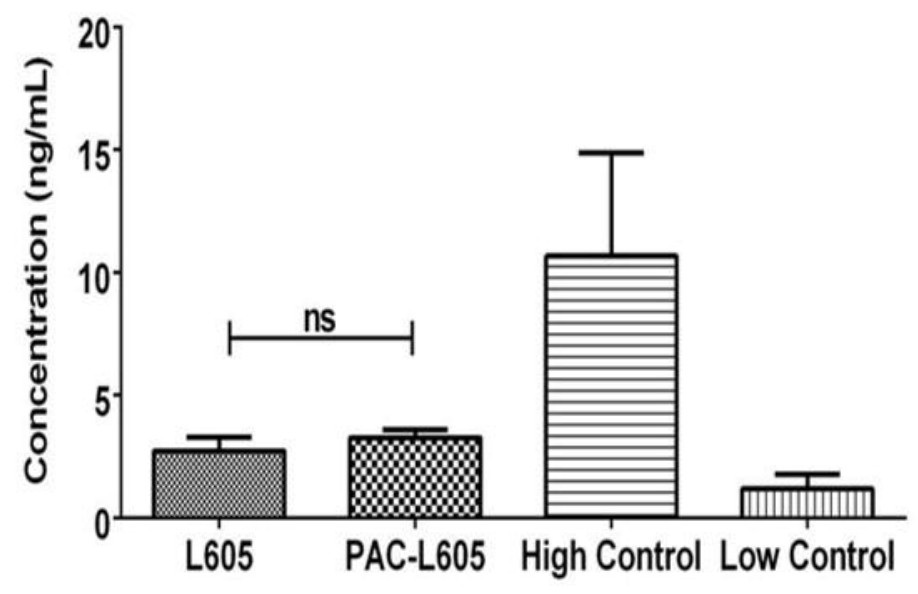




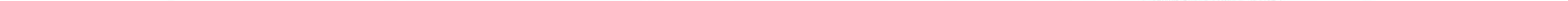

